\title{
BILLS OF LADING AND FACTORS IN NINETEENTH CENTURY ENGLISH OVERSEAS TRADE
}

\author{
Noraran I. MmLER †
}

$\mathrm{F}$ OR ENGLISH commercial law, no less than for English society as a whole, the nineteenth century was a period of great readjustment. The move from an agricultural into an industrial economy confronted the courts with a multiplicity of problems, the successful solution of which demanded not only legal facility, but also an appreciation of the needs which they represented and the context from which they arose. Although there is an abundancy of legal writing on the bill of exchange and the evolution of banking, the development of the bill of lading in relation to commercial banking appears to have been largely ignored by legal historians. The purpose of this article is to attempt in some measure to rectify this omission by revealing how the courts adjusted to and recognized the operations of the factor and the use of the bill of lading in the financing of international trade in the nineteenth century.

\section{Overseas Trade Patterns of the Nineteenth Century}

Prior to 1815, the patterns of English foreign trade were somewhat differentiated as between exports and imports. In the importing field trade was carried on by consignments. ${ }^{1}$ Under this pattern the overseas producer would make up a cargo, generally of raw materials, and ship it to his English correspondent who would sell it for the producer's account. This system, which had been in operation for many years, was mainly the outcome of the geographic distance between the origin of capital and its actual sphere of operations, and of the technological difference between England and the underdeveloped countries. ${ }^{2}$ The absence of any banking facilities in the latter areas made the foreign producer particularly dependent upon the financial aid which he could obtain from the merchant; ${ }^{3}$ and by so doing, of course, it placed the latter in a position whereby he could maximize his own resources to the fullest possible extent with a minimum of risk as regards a fall in the market price of the goods. ${ }^{4}$

† Law and Behavioral Science Research Fellow, University of Chicago Law School.

${ }^{1}$ Parliamentary Papers (Great Britain), Report from the Select Committee on the Law Relating to Merchants, Agents or Factors, 4 Session 1823, 17 (henceforth referred to as Parl. Papers, Report on Merchants, 1823). For a detailed description of this system consult discussion at 258-59 infra.

2 Greenberg, British Trade and the Opening of China, 1800-1842, 144 (1951); 1 Clapham, An Economic History of Modern Britain 254 (2d ed., 1930).

3 Parl. Papers, Report on Merchants, 1823, 7.

4 Clapham, op. cit. supra note 2, at 254. 
In the export market, however, the fact that domestic production had not as yet outstripped the needs of either the foreign or domestic market made the demands for the former to a large extent both regular and calculable. ${ }^{5}$ Export merchandising during this period was thus founded on an order basis: the merchant ${ }^{6}$ purchased the goods outright from the manufacturer and sent them abroad to meet specific orders or to satisfy the foreseeable requirements of the market generally. ${ }^{\top}$

Although the manufacturing output in England had been steadily growing since the turn of the century, the transition from small to large scale production gathered greater momentum after $1815 .^{8}$ The increase in the volume of goods produced in England after the Napoleonic Wars ${ }^{9}$ had the effect of upsetting the

s Adam Smith, who saw something of the development in British foreign trade before his death in 1790, was fond of pointing out that the home trade was more important than the foreign. The progress of Britain's overseas trade quickened remarkably, however, in the last twenty years of the eighteenth century although the outbreak of war with France in 1793 did produce a temporary lull in this expansion. The hostilities prevented the new industrial equipment which was then evolving from having its full effects on world markets. Court, A Concise Economic History of Britain 73-74 (1954).

- The merchant, as distinguished from the factor or commission merchant, was a trader who dealt in goods mainly for his own account and assumed the risks of loss or depreciation himself. The factor, as his name implies, bought and sold on the account of others, deriving his profit from a percentage commission on the amount spent or realized. It was seldom, however, that individuals engaged exclusively in one of these activities; though in some trades, such as linen, this did appear to be the rule. When the trader did operate in both capacities, the difference in nomenclature was based upon a quantitative distinction. Buck, The Development of the Organization of Anglo-American Trade 1800-1850, 5-6 (1925).

7 Ibid., at 99-105. Until the end of the Napoleonic Wars, merchants buying on their own account in the English market still engaged in the old practice of "adventuring"; i.e., purchasing goods outright, loading them on a hired vessel, and then attempting to seek an outlet for them abroad. The risk involved in such endeavors was in most instances minimized by the merchants' knowledge of the demands of the foreign markets. After the crises of 1816 and 1825, however, this method of export lost much of its popularity, though it still persisted in the more primitive trades such as grey cotton cloth. Clapham, op. cit. supra note 2, at $254 ; 2$ ibid., at 313; Postan, Credit in Medieval Trade, 1 Econ. Hist. Rev. 234 (1928), reprinted in Essays in Economic History 105-71 (Carus-Wilson, ed., 1954).

8 The following table showing the amount of cotton cloth printed in illustrative years before and after the end of the Napoleonic Wars (1815) illustrates the phenomenal rate at which this development took place:

$\begin{array}{cc}\text { YARDS OF CLOTH PRINTED IN GREAT BRITAIN } \\ \text { Year } \\ \text { Yards } \\ 1796 & 20,621,797 \\ 1800 & 32,869,729 \\ 1814 & 124,613,472 \\ 1830 & 347,450,299\end{array}$

Porter, Progress of the Nation 305 (Hirst, ed., 1912). By 182\%-30, the cotton industry accounted for about one-half of the value of British exports. Court, op. cit. supra note 5 , at 178 .

- Industrial production during this period increased on the average of 3.4 per cent per annum, as compared with 2 per cent during the period 1800-1815. The rate of growth of the English population from 1800-1873 never rose far above 1 per cent. Court, op. cit. supra note 5, at 177;2 Gayer, Rostow, and Schwartz, The Growth and Fluctuation of the British Economy 625 (1953). 
equilibrium of the market to the extent that the manufacturer could no longer rely upon specific orders to absorb all of his output. ${ }^{10} \mathrm{He}$ was thus compelled to undertake some of the tasks and most of the risks of merchandising in order to dispose of his surplus. Since it was not in the manufacturer's interest to depress the domestic market by dumping such surplus at home, a considerable amount of his efforts was directed toward foreign markets. ${ }^{11}$ The impact of this increased effort upon the methods of dealing that had hitherto prevailed in these areas was two-fold. Not only did regular export trading to order give way almost entirely to consignment sales, ${ }^{12}$ but the merchant who had been accustomed to controlling the various transactions in this field was forced to change the pattern of his operations also. Whereas formerly he had undertaken the disposal of most of these goods abroad for his own account, he now found himself forced to compete with many of the stronger manufacturers. The risks involved in such competition were altogether too great for the export merchant to accept alone.13 From dealing largely as his own principal before 1815 , he moved rapidly into the role of a mercantile agent, trading, as in the import field, mainly for the account of others. For the next fifty years or so, he was to dominate the trading scene not in the dual functional capacity as importer and exporter, but solely as a general commission merchant-a factor..$^{14}$

The reasons for this dominance are not hard to find. Under the consignment method of trading a domestic manufacturer could send his surplus goods either directly to his own overseas agent or else to a British merchant situated in

${ }^{10}$ Parliamentary Papers (Great Britain), Report from the Select Committee on the Present State of Manufactures, Commerce and Shipping in the United Kingdom, 6 Session 1833, 91 and passim (henceforth referred to as Parl. Papers, Report on Manufactures, 1833). In his testimony before the Committee, one of the witnesses, a commission merchant, stated that "[t]he manufacturers in England are obliged to operate upon a very large scale; they have a regular demand for two-thirds or three-fourths of what they make, and the rest they ship...." Ibid., at 93.

11 Thus, for example, of approximately three million yards of cotton cloth printed in 1830, less than half was used in the domestic market. Porter, op. cit. supra note 8, at 305 . Based on official values of this period, exports increased almost ten times from 1800 to 1853 . In real value, however, they just about trebled themselves. Imlah, Real Values in British Foreign Trade 1798-1853, 8 J. Econ. Hist. 133 (1948); Porter, op. cit. supra note 8, at 477, 518.

12 Parl. Papers, Report on Manufactures, $1833,35,61,93,126,141$. Consult also Buck, op. cit. supra note 6, at 122-24; Greenberg, op. cit. supra note 2, at 144.

13 Parl. Papers, Report on Manufactures, 1833,141 . This was especially so in the American market where many of these consignments were disposed of by auction at losses as high as 60 per cent. Buck, op. cit. supra note 6 , at 138 . As Llewellyn points out, the prerequisite for factorage is the seller's need to ship to a market whose conditions on the arrival of his wares are beyond his foresight. Llewellyn, The First Struggle to Unhorse Sales, 52 Harv. L. Rev. 873, 884 (1939).

${ }^{14}$ According to one estimate made in 1834, more than two-thirds of the entire trade of Great Britain, both imports and exports, were handled by commission merchants. Lord Liverpool in the House of Lords, quoted by McCullock, A Dictionary, Practical Theoretical and Historical of Commerce and Commercial Navigation, 571 (2d ed., 1834). 
England who, for a small percentage commission, ${ }^{15}$ would undertake the responsibility of shipping the goods abroad and selling them for him. ${ }^{16} \mathrm{In}$ either case, however, the attendant risk of depreciation in the value of the goods always remained with the manufacturer..$^{17}$

For the average manufacturer, the use of the commission merchant was clearly the more advantageous procedure. Not only were the trading connections already established by the latter placed at his disposal, but the merchant's specialized knowledge of the market and the various techniques of shipping and insurance were also made available to him. Of even greater importance than these services, however, were the credit facilities which the commission merchant offered the manufacturer. Instead of having to wait for his money until the goods were sold, a practice which only the strongest manufacturer could afford, ${ }^{18}$ he was permitted to draw on the factor for approximately two-thirds of the estimated value of the consignment as soon as the goods were ready for shipment overseas. Once the bill of exchange was accepted by the commission merchant it became readily discountable in the money market, thereby enabling the consignor to obtain control of funds despite the fact that his products were as yet unsold. ${ }^{19}$

By the early 1820's, it is clear that this method of dealing was predominant in both the English import and export trade. ${ }^{20}$ Not only did this pattern of trading benefit the manufacturer and producer, but the attractiveness of the com-

${ }^{15}$ In 1801 the commission paid by manufacturers to their factors was 5 per cent of the sale price of the goods. This included warehouse and del credere charges. The import factor generally charged 2 or $2 \frac{1}{2}$ per cent, depending upon the origin of the shipment. Buck, op. cit. supra note 6, at 15; Hidy, The House of Baring in American Trade and Finance 12 (1949). As competition among Factors increased, especially in the cotton trade, these commissions were reduced. Ellison, The Cotton Trade of Great Britain 279 (1886).

${ }^{16}$ Buck, op. cit. supra note 6, at 122-29.

${ }_{17}$ The risk was primarily one of depreciation in market price. The expansion of the services of Lloyd's underwriters after 1793 enabled the owner to insure against the risk of loss in transit to and from the remotest markets. Court, op. cit. supra note 5, at 79. The insurance was invariably effected by the factor, however.

${ }^{18}$ For example, manufacturers consigning their goods directly to the India market had to wait about eighteen or nineteen months for receipt of the proceeds of sale. The voyage alone took ten months. Parl. Papers, Report on Manufactures, 1833, 142.

${ }^{19}$ Parl. Papers, Report on Merchants, 1823, 12. This system operated in exactly the same manner for the overseas producer, except that he would generally consign his goods to a correspondent of a British commission house located in his own country, and obtain his advances directly from him. The latter would forward the shipment on to the commission merchant in England who would then undertake its disposal. Parl. Papers, Report on Merchants, 1823, 7.

${ }^{20}$ In its report of 1823 , a select committee of Parliament states: "The growth of our commerce appears to have gradually led to greater extension of credit, and facilities in pecuniary advances have increased in proportion as our trade generally has extended; and it is proved, to the entire satisfaction of Your Committee ... that the merchants of Great Britain are constantly in the habit of making advances on merchandize consigned to them for sale." Parl. Papers, Report on Merchants, 1823, 11. 
mission and the security for the credit advances gave the merchant even more of an incentive to engage in this type of transaction than the consignor. ${ }^{21}$ Thus not only was he always willing to accept the latter's consignments: in many instances he actively sought them. ${ }^{22}$

The factor's advantage in having a self-liquidating security always available as protection for his advances was further increased by the ease and facility with which this security could be handled. For many decades merchants had been accustomed to dealing with bills of lading in lieu of goods, while the latter were still at sea. ${ }^{23}$ In their hands it had achieved a flexibility which to some extent rivalled that of another mercantile bill, the bill of exchange. ${ }^{24}$ This practice of dealing in goods by way of documents enabled the factor to recover his advances long before the consignment itself arrived at the market of sale, ${ }^{25}$ and by so doing gave him access to funds with which to finance further transactions of this nature. Even more important than the speedy liquidation of debt was the fact that such a device was susceptible to use beyond the immediate confines of factor and consignor. Although generally speaking, the commission merchant

21 "Receiving consignments is the business we primarily wish for," said Joshua Bates in 1831 , as manager of Baring Bros., one of the largest of the commission merchant houses. Hidy, op. cit. supra note 15 , at 105 .

Advertisements, such as the following, which shows the American partners of the Liverpool firm of Brown and Shipley canvassing for such shipments, were typical of this period: "Should you send us cotton or other produce, we will either dispose of it in this market [i.e., the American], or re-ship it to our Liverpool house. . . . We are willing, at all times, to make reasonable advances on property consigned to us, or our Liverpool house." Brown, A Hundred Years of Merchant Banking, 190-91 (1909).

22 Parl. Papers, Report on Merchants, 1823, 89. "Immediately after the peace of the country was consolidated, there were men issued out from Liverpool, calling themselves merchants, going around from warehouse to warehouse, like number carriers, like hawkers of goods, and requesting consignments; they said they were doing business with Rio Janeiro, and other ports and they could as well sell $£ 10,000$ of goods along with theirs as not." Parliamentary Papers (Great Britain), Report from the Select Committee on Petitions from the Hand-Loom Weavers, 10 Session 1834, 424, quoted by Buck, op. cit. supra note 6 , at 127 . The houses doing this type of business became known as "slaughterhouses" because of the effect their underselling had on the smaller manufacturers and upon trade in general. Ibid.

${ }^{23}$ The earliest case at law mentioning the assignment of a bill of lading is Evans v. Marlett, 1 Ld. Raym. 271 (K.B., 1697). There appears to be abundant evidence, however, that the practice was widespread at a much earlier date. Consult 1 Select Pleas of the Court of Admiralty 44; 2 ibid., at 61, 63, 146 (Selden Society).

24 The origin of the practice of assigning a bill of lading by indorsement and delivery is not clear. From the opinion of Buller, J. in Lickbarrow v. Mason, 2 T.R. 63 (K.B., 1787), it would appear that such a custom was well entrenched by 1787 . And the remarks of the Privy Council in Henderson v. The Comptoir D'Escompte De Paris, L.R. 5 P.C. 253 (1873), in which the omission of the words "to order or assigns" on a bill of lading are discussed, suggest that the bill had never been conceived of as anything but negotiable by those engaged in international trade.

${ }^{25}$ The initial impact of steam navigation only served to emphasize the difference between mail and cargo arrivals. In the East Indian trade, for example, dispatches from London to Bom. bay during the late thirties averaged between sir and nine weeks as against five months for the cargo; while the Atlantic crossing was reduced from over fifty to less than fifteen days by the mail packets operating in 1840 . Porter, op. cit. supra note 8 , at $539,542$. 
was, up to about 1850 , the direct purveyor of credit to the exporting manufacturer and producer, he in turn was accustomed to receiving advances from a bill broker, who often borrowed from the banker. ${ }^{26}$

Originally this chain of credit was based wholly upon the security of the bill of lading. In exchange for the advances, the commission merchant would transfer the document to the broker, who would pay the freight and other charges incidental to the safe custody of the goods and once they were sold reimburse himself from the proceeds. ${ }^{27}$ Later, as transportation time diminished and new so-called "documents of title,"28 such as the dock warrant and the wharfinger's receipt emerged, ${ }^{29}$ financing began to build up around these instruments also. ${ }^{30}$ The entire process is described as follows in the Parliamentary Report on Commercial Distress, 1848:

The Merchant ... if he has not sufficient Capital [i.e. to meet his acceptances] has to pledge that Produce (which he imports) with the Broker till he has Time to sell that Produce. Then a new Species of Bill is immediately drawn by the Merchant :...

${ }^{26}$ Parl. Papers, Report on Merchants, 1823, 11, 17. The bill broker, or discount house, to whom the consignor turned to discount his acceptances borrowed the surplus funds of the banker in order to meet these demands also. The security of the banks was provided by the bills themselves, which arising as they did from actual sales transactions were regarded as A-1 paper.

${ }^{27}$ Tbid., at 110, 113, 117; Evans, The City (or The Physiology of London Business) 177 (1845).

28 Under the Factors Act of 1842, documents of title included "any Bill of Lading, India Warrant, Dock Warrant, Warehouse Keeper's Certificate, Warrant, or Order for the Delivery of Goods, or any other Document used on the ordinary Course of Business as Proof of the Possession or Control of Goods, or authorising or purporting to authorise, either by Indorsement or by Delivery, the Possessor of such Document to transfer or receive Goods thereby represented." Apart from the reference to the "India Warrant," which went out of use, this definition was readopted by the codifying Act of 1889.5 \& 6 Vict., c. $39 \S 4$ (1842), as amended $52 \& 53$ Vict., c. $45, \S 4$ (1889).

29 Although the practice of dealing in these other documents in lieu of the goods existed before 1815, the attitude of the courts was equivocal as to whether the same effect should be given to documents relating to goods on shore and those at sea. In Spear v. Travers, 4 Camp. 251,253 (N.P., 1815), the special jury was of the opinion "that in practice, the indorsed dock warrants and certificates are handed from seller to buyer as a complete transfer of the goods." Parke, B., however, in Farina v. Home, 16 L.J. Ex. 73 (1846), adopted Blackburn's view that the transfer of such documents did not operate per se as delivery of possession of the goods in the same way as a bill of lading; but that a further act of attornment was necessary before this was accomplished. Ibid., at 75. Blackburn, Sales 297 (1st ed., 1845). It was the latter view that eventually prevailed. Today delivery orders and dock warrants are seldom used by trade financiers as collateral because of this reason, save in those instances where the dock company has obtained a private Act of Parliament making its dock warrants negotiable. Gutteridge and Megrah, The Law of Bankers' Commercial Credits $133 \mathrm{n}$. (h) (1955).

${ }^{30}$ This, despite the legal uncertainty concerning the use of these documents as collateral. It is not without significance that Overend and Guerney, one of the largest discount houses in the City of London, had willingly accepted these documents as security prior to its collapse in 1866. Parliamentary Papers (Great Britain), Report from the Select Committee on Bank Acts, 1 Session 1857, 489-90 (evidence given by D. B. Chapman, managing partner in Overend and Guerney) (henceforth referred to as Parl. Papers, Report on Bank Acts, 1857); Evan, Facts, Failures and Frauds: Revelations Financial, Mercantile, Criminal 179, 199, 701 (1856). 
upon the Broker on the Security ... . lodged in the Warehouse ... bonded or free. Then it is the business of the Banker to ascertain from the Broker whether he has the Produce and to what extent he has advanced upon it. It is his business to see that the Broker has Property to protect himself if he make a loss. ${ }^{31}$

It was, of course, the ease and safety which the documentary form of security imparted to the financing operation which enabled the chain of credit to be extended beyond the original participants in the consignment trade. The increasing awareness of the advantages of the system made the non-merchant financier only too eager to advance his money on such security. ${ }^{32}$ Indeed, by the 1830's the acquisition of credit from these individuals had already become a matter of merely endorsing over a bill of lading. ${ }^{33}$

For the established commission merchant, this easy access to credit was not an entirely unmixed blessing. Factors were actively competing with one another in the late twenties to secure consignments; the willingness of the banker, broker and discount house to advance on the documentary security only gave impetus to this competition, since it enabled the commission merchant to increase his own loans to the consignor as an added inducement for the latter's trade. Advances during the thirties were thus considerably in excess of those offered in the previous decade. ${ }^{34}$

Another result of this ready availability of credit was that it added to the speculative practices which were permeating English commercial life generally during the period $1830-1850 .{ }^{36}$ Numerous complaints were leveled by the older and more experienced members of the merchant community against the indiscriminate lending practiced by the bankers, discount houses and brokers solely on the basis of documentary collateral. Especially bitter were the attacks made in connection with the East India trade, ${ }^{36}$ where many abusive practices had

31 Parliamentary Papers (Great Britain), Report from the Secret Committee of the House of Lords appointed to inquire into the Causes of Distress which has for some time prevailed among the Commercial Classes, and how far it has been affected by the Laws for regulating the Issue of Bank Notes payable on Demand, together with minutes of Evidence, and an Appendix, 24 Session 1847-1848, 283, quoted by Buck, op. cit. supra note 6, at 24; Parl. Papers, Report on Merchants, 1823, 113.

32 Parliamentary Papers (Great Britain), Report from the Secret Committee of the House of Commons on Commercial Distress, Session 1847-1848 (1st rep.) 73-74 (henceforth referred to as Parl. Papers, Report on Commercial Distress, 1847-1848 [1st rep.]).

${ }^{33}$ Tbid., at 55,74 .

34 By the 1840's it was over 90 per cent in some cases. Parl. Papers, Report on Commercial Distress, $1847-1848$ (2d rep.) 117.

${ }^{35}$ The consignment trade itself was, of course, essentially speculative in nature. Parl. Papers, Report on Manufactures, 1833, 35-37, 127; Buck, op. cit. supra note 6, at 126.

${ }^{36}$ The East India Company was charged with unfair competition in using the bill of lading as a means of remitting its annual balance of about three million pounds sterling to England. This it did by the simple expedient of purchasing the documentary drafts (i.e., the bills of exchange drawn on an English correspondent to which the bills of lading and other shipping documents were attached) of merchants in India who were consigning goods to England. These drafts were then sent to London, and the company had merely to await the arrival of the cargo in Britain and the taking up of the bill of the exchange by the consignee. If the latter failed to 
grown up as a result of this credit situation. A typical example was the habit of many Calcutta merchants to purchase outgoing cargoes consigned to England, give a draft upon their correspondents in London as payment, and then send the bill of lading home to England. Notwithstanding the fact that the bill of lading traveling overland arrived in England within six weeks or so, the bill of exchange was nevertheless drawn to mature only upon the arrival of the cargo, some ten months after shipment. Thus, although the bill of exchange arrived at the same time as the bill of lading and was then accepted by their correspondent, it still had eight months to run after the time of its arrival in England. By pledging the bill of lading with either a produce or discount broker as security for advances, the correspondent had eight months free use of the money before his acceptance matured. ${ }^{37}$

The reason why the older commission merchants were so critical of those who made advances solely on the basis of the documentary security to houses indulging in practices of this nature was that no account was taken of the inherent financial instability which these trading methods indicated. As they saw it, such houses were an extremely bad credit risk despite the existence of an apparently iron-clad security. The indifference of these financiers to anything beyond the immediate possession of the documentary collatera ${ }^{38}$ not only encouraged the continuation of the abuses themselves, it also effectively concealed the true nature of the credit risk until it was too late, and the borrower went completely bankrupt. ${ }^{39}$

So long as such a liberal credit policy rested upon actual commercial transactions, however, the financial risks for the creditor were comparatively small. It was when acceptances were granted without the acquisition of any security, documentary or otherwise, that the lender exposed himself to very real peril. The granting of open credits and accommodation bills ${ }^{40}$ was not new, of course;

take up the draft, the bill of lading enabled the Company to obtain possession of the goods and recover its outlay from the proceeds of sale.

This procedure naturally deprived the English commission merchant of a lucrative source of profit, since instead of having to rely upon him for his funds, the consignor obtained them directly from the East India Company, thereby giving the latter the benefit of the commission on such advances. Parl. Papers, Report on Commercial Distress, 1847-1848 (2d rep.) 107-19; Radford, Manchester Merchants and Foreign Trade 1794-1858, 123-25 (1934).

${ }^{37}$ Parl. Papers, Report on Commercial Distress, 1847-1848 (2d rep.) 118.

${ }^{38}$ That this complacency was not entirely justified is shown by the famous Cole and Davidson trade frauds of 1859 in which Overend and Guerney, the largest of the discount houses, was somewhat discreditably involved. Seven years later, this particular firm crashed.

${ }^{39}$ Parl. Papers, Report on Commercial Distress, 1847-1848 (1st rep.) 14.

${ }^{40} \mathrm{An}$ open credit in international trade was one in which the remittance, either in the form of produce or some other security, was not made contemporaneously with the acceptance. It was granted solely on the basis of something to be done in the future before the acceptance matured. Parliamentary Papers, Report from the Select Committee on the Bank Acts, Session 1858,114 (henceforth referred to as Parl. Papers, Report on Bank Acts, 1858). So long as they were used cautiously, open credits were always recognized as an integral part of the credit system. It was the abuse that proved objectionable. Ibid., at 115-16. 
the old and established merchant houses had dealt for many years in credits which had no identified security. ${ }^{41}$ Their issuance, however, had always depended upon the extremely high reputation of the person for whom the bills were accepted..$^{42}$ With the tremendous competition in the overseas trade that arose during this period, many of the commission merchants abandoned, or were forced to abandon, their habitual caution in this respect. ${ }^{43}$ The 1857 crisis was a sharp reminder of the perils of such speculative practices. ${ }^{44}$

Although the risk to creditors was comparatively small when the paper which they held stemmed directly from an actual sales transaction, even amongst this type of acceptance a considerable difference could exist as to soundness. Since the bill was an order by one party to pay another a sum of money, generally at a subsequent date, the ability of the party on whom the bill was drawn to meet it at the appointed date was a factor of overwhelming importance. It was clear to the merchants of the early nineteenth century (and this is just as true today) that a bill accepted by a small tradesman had no value outside the confines of his own locality. An acceptance of a great merchant house of unquestionable standing, on the other hand, was an easily negotiable credit instrument, and also an ideal form of investment for bankers and brokers who had to keep their resources liquid. If cash were required immediately, it could be discounted at a small charge; if not, the holder could await the date of maturity and then collect from the acceptor.

Long before 1850, the larger commission houses were doing a thriving business in lending their credit to smaller factorage concerns. The practice whereby the consignor drew his bill upon one of these larger houses instead of drawing it

41 Bankers were, thus, obviously reluctant to discount accommodation bills. Klein, The Development of Mercantile Instruments of Credit, 12 J. of Acc. (N.Y.) 321, 604-5 (1911). The danger of having no solid foundation on the issuance of a bill of exchange can be seen by the following example. A grants B an open credit. B draws a bill on A for four months; A accepts it and then $B$ discounts the acceptance. $B$ then sends $A$ another draft within four months, also not drawn against a bill of lading. $A$ accepts this draft also, and $B$ again discounts it and uses the proceeds to put $A$ in funds in order to meet the just-matured acceptance. In 1857, sixteen houses in A's position collapsed. Parl. Papers, Report on Bank Acts, 1858, 119.

${ }^{42}$ Hidy, op. cit. supra note 15, at 139, 297.

${ }^{43}$ Buck, op. cit. supra note 6 , at 156-58. It was in an attempt to overcome the hazards of the open credit that Baring Bros. devised a receipt in the thirties by which all property purchased by means of the credit, together with "the proceeds thereof and the policies of insurance," were pledged and hypothecated with it as collateral security for repayment of the advance. This was, in effect, the forerunner of the modern trust receipt. Hidy, op. cit. supra note 15, at 142; see Fletcher v. Morey, 2 Story 555 (C.C., 1843), where the legal effect of this receipt was discussed. Compare the form of hypothecation agreement required by the East India Company in its dealings. Parl. Papers, Report on Commercial Distress, 1847-1848 (2d rep.) 135-36.

${ }^{44}$ Commission merchants who endeavored to obtain some collateral for their speculative activities often made advances to planter-consignors on the security of the latter's growing crops. Especially during the feverish period of 1847-57, the not infrequent failure of the growers resulted in the merchants becoming planters, which, in turn, placed an additional financial strain on their resources. A number of factorage concerns collapsed in 1857 as a result of this type of operation. Parl. Papers, Report on Bank Acts. 1858. 112-13. 
directly upon the consignee was known at the beginning of the century, but its use did not become systematic until after $1800 .{ }^{45}$ In essence, this type of financing did not differ from the credit services offered by the factor-consignee: the pivot of both transactions still being the documentary security afforded by the bill of lading. Instead of the consignor drawing directly on the factor, however, and remitting both the draft and the shipping documents to him, he would draw upon some large and well-established house designated by his consignee and send the bill of exchange and shipping documents directly to that concern. ${ }^{46}$ The latter would accept the bill and return it to the consignor, while retaining the shipping documents for subsequent transference to the consignee. ${ }^{47}$

This system of documentary credits, as it was called, began to gain prominence during the 1850's. Its widespread use reflected not only the growing strength of the seller's position and the decline of the consignment method of dealing which was manifesting itself about this time but the bifurcation of the financing and trading function which was taking place within the mercantile community. This division never really became clear-cut, however, until after 1860 when the consignment pattern had largely disappeared. ${ }^{48}$

The disappearance of the consignment pattern was evident by 1850 . Not only was trading to order re-established in many of the foreign markets, ${ }^{49}$ but new patterns of dealing were also emerging..$^{50}$ These developments, together with the gradual stabilization of trade generally, made the disappearance of factorage as a large scale activity inevitable..$^{51}$ For the commission merchant, the alternative was either to revert to his former role as importer or exporter for his

${ }^{45}$ Hidy, in his account of the growth of Baring Bros., shows how the firm's movement into the acceptance business was accelerated after the turn of the century. Hidy, op. cit. supra note 15 , at 15 and passim.

16 Ibid., at 136, 147. Buck, op. cit. supra note 6, at 155 .

${ }^{17}$ During the periods of intense speculation in the middle part of the century, the acceptance house would retain the bill of lading until it received the amount of the acceptance plus interest and commission from the consignee. In some cases the latter would also be required to deposit additional security in the form of 10 per cent of the estimated value of the goods, 65 Edinb. Rev. 220 (1837); Brown, A Hundred Years of Merchant Banking 250 (1909); Hidy, op. cit. supra note 15, at 136-37; Buck, op. cit. supra note 6, at 156.

48 The introduction of telegraphic communication in 1837 and the successful laying of the Continental and Atlantic cables in 1851 and 1866 were in themselves largely responsible for the decline of the consignment trade. 2 Clapham, op. cit. supra note 2, at 315-17. As long as the pattern persisted, the houses engaged in the acceptance business still continued the two operations: the $2 \frac{1}{2}$ per cent commission on such sales being too safe and too lucrative a source of profit to be abandoned easily.

49 Though in some of the more remote trades, such as those of the Black Sea and the Barbary Coast, the consignment pattern persisted for some time, as it did in certain commodities such as wool. Tbid., at 317.

so For example, dealing in arrivals and futures.

51 Ibid., at 316; Buck, op. cit. supra note 6, at 152. For an illuminating discussion of the revival of factorage in the present century, consult Steffen and Danziger, The Rebirth of the Commercial Factor, 36 Col. L. Rev. 745 (1936). 
own account, ${ }^{52}$ or, if strong enough, to move directly and exclusively into the field of buyer financing by means of the documentary credit..53

It was from the latter movement of these one-time large factoring concerns that the modern merchant banker emerged. Firms which originally had been the dominant traders in one area or commodity now became the chief source of finance in the same area. Though these "acceptance houses," as they came to be called, did not limit their activities to particular commodities or countries, each of them had its own special realm, both geographically and by commodity. ${ }^{54}$

By the late 1860's it was clear that, if some of these houses were not as yet fully matured banking institutions, all of them were nevertheless pre-eminent in the field of foreign trade finance. Their knowledge of particular markets and the reputation of those trading in them, which they had acquired as factors, gave them a tremendous advantage over other purveyors of credit. ${ }^{55}$ It was this, combined with the flexibility of the documentary system itself, ${ }^{56}$ that permitted them to operate so easily and effectively, and enabled them to establish their supremacy in this highly specialized area:57 a position which they have maintained ever since.

${ }^{52}$ Clapham, op. cit. supra note 2, at 315.

${ }^{63}$ In the Far Eastern trade, however, the commission merchants became industrial entrepreneurs giving rise to what Greenberg calls "the managing agency system." Greenberg, op. cit. supra note 2 , at 144 .

${ }^{54}$ Truptil, British Banks and the London Money Market 132 (1936). For a history of these various concerns, consult Ashley, The Story of the Banks 186-91 (1934).

${ }^{56}$ The English joint stock banks did not enter this field until the turn of the century. Thackstone, The Methods of Financing Foreign Trade: The Part Played by the Banks 125, 128; Banking and Foreign Trade, Lectures Delivered at the Fifth International Banking Summer School (1952).

${ }^{56}$ The acceptance credit was of great value in expanding the Far Eastern trade. The British demand for Chinese goods during the nineteenth century was so much greater than the latter's demands for British goods that the problem of payment became very real. Acceptances drawn on such well-known houses as Baring and Co. and Jardine Matheson \& Co. enabled cargoes to be purchased without the need for shipping specie to such areas. Buck, op. cit. supra note 6, at 158; Truptil, op. cit. supra note 54, at 132; Hidy, op. cit. supra note 15, at 74, $104,113,232$. For the best account of trade in this area, however, consult Greenberg, op. cit. supra note 2 , at c. 1 .

${ }^{57}$ One of the important factors which influenced and stimulated the growth of these concerns in the nineteenth century was the misfortune which befell many of England's old time trading rivals. Holland had been beaten in an unlucky war and had lost the greater part of her Indian possessions, as well as a number of her vessels. Her financial prestige had been badly shaken by the failure in 1796 of the 200-year-old Bank of Amsterdam. England, on the other hand, had secured her position in the richest parts of India, while the port of London had made gigantic strides and had become by the turn of the century the center of the entrepot trade. The wars of the French Republic had not only set back French trade, they had stimulated English commerce and industry which, in turn, had given additional impetus to the multiplicity of demands for credits. In addition, the influx of merchants from Germany, Holland and Denmark meant the establishment of houses in London which possessed both wealth and reputation of international standing. Truptil, op. cit. supra note 54, at 137 et seq.; Ashley, op. cit. supra note 54, at 186-91; Withers and Palgrave, The English Banking System, reported in Sen. Doc. No. 492, 61st Cong. 2d Sess. 53-54 (1910). 


\section{Legal Recognttion of the BLL of Lading as AN INSTRUMIENT OF CREDIT}

The preceding description of the trade patterns of the nineteenth century indicates that the development of the bill of lading by the merchant and banking community as the central pivot of international trade finance was accomplished with no great difficulty. For the lawyer, on the other hand, since in most instances he was unfamiliar with commercial practice, the task of according appropriate legal recognition to this development was not so easy. This is not surprising when one considers that the structure of English life up to the latter part of the eighteenth century was predominantly rural in nature. Land and agriculture were the axes about which most of life revolved ${ }^{58}$ and commerce was so far removed from what were regarded as the normal activities of the bulk of the population that it was not until 1690 that the courts gave effect to a bill of exchange to which a non-merchant was a party.59

The conceptual nature of legal thinking during this period, geared, as it was, to satisfying the requirements of an agricultural community rather than the needs of a commercial and industrial society also added to these difficulties. Much of the embarrassment which the courts were to experience when dealing with bills of lading, and, indeed, most of those connected with overseas sales, stemmed from their inability to see the concept of "property" as anything less than a unitary whole. ${ }^{60}$ When "property" in goods was transferred by way of indorsement and delivery of a bill of lading, the judiciary at this time had difficulty construing this as anything other than the transference of complete ownership, regardless of the nature of the transaction.11

To distinguish between the use of the bill of lading as a security instrument and as a trading device-that is, between a transfer of a limited interest in the goods as collateral for an advance of credit, ${ }^{62}$ and a transfer of the entire interest pursuant to a contract of sale-compelled judges both to educate themselves in

${ }^{68}$ Court, op. cit. supra note 5 , at c. 2.

${ }^{59}$ Witherley v. Sarsfield, 1 Show. 815 (Ex. Ch., 1690).

${ }^{60}$ Consult Llewellyn, Across Sales on Horseback, 52 Harv. L. Rev. 725 (1939). See also Hardy \& Co. v. Fillerns \& Fowler [1923] 2 K.B. 490, and Chao v. British Traders Ltd. [1954], 1 All E. Rep. 779 (K.B.), for examples of the difficulties which this concept can cause.

61 The ownership restrictions known in land law were extremely difficult to analogize successfully with chattels, although by the eighteenth century most mortgage transactions were coming before the courts of equity. The old common law mortgages would probably not have helped to illuminate the situation because, as Plucknett points out, they "suffered from the incurable defect that they employed formulas which contradicted the true nature of the operation-they spoke of feoffments in fee, and leases for years, when the transaction was really neither - and such forms inevitably attracted several doctrines of seisin and the derivation of estates, which tended to defeat their purpose." Plucknett, A Concise History of the Common Law 573 (4th ed., 1948).

62 The bill of lading could also be used as a means of securing the payment of the purchase price by the buyer. See Meyer v. Sharpe, 5 Taunt. 74 (C.P., 1813); Mirabita v. Imperial Ottoman Bank, 3 Ex. D. 164 (1878). 
the ways of the commercial world and also to readjust their modes of thought to meet the demands of this new economic order. For most of them, the process was as slow as it was painful.

The earliest reference to the legal effect of the transfer of a bill of lading, according to Lord Tenterden in his classical work on the Law of Shipping, ${ }^{63}$ was the decision of Evans v. Martlett in $1697 .^{64}$ There the opinion was expressed by Chief Justice Holt that the consignee of a bill of lading had sufficient "property" in the goods to assign ${ }^{65}$ the document to a third party. ${ }^{66} \mathrm{Just}$ what was meant by "property," however, is not clear since the report itself gives very few details as to the facts of the case.

Probably the first occasion in which the question of assignability and its effect actually came directly before a law court was Snee v. Prescotti7 in 1743. This was an action by the assignees in bankruptcy of a consignee, $T$, to recover from the London agent of the consignors certain silks which the latter had shipped to $T$. It appeared that the consignor, $R$ ( $T$ 's partner in Italy), had obtained certain silks for T's account and in so doing had advanced money on T's behalf. The bill of lading for the silks was made out to R's order, indorsed by him in blank, and sent to $T$. $T$ assigned it to $B$ as security for advances. After the goods were shipped $T$ went bankrupt, but on their arrival R's agent presented a copy of the bill of lading to the ship's master and managed to obtain

${ }^{63}$ Abbot, Law of Shipping 844 (14th ed., 1901).

$641 \mathrm{Ld}$. Raym. 271, 3 Salk 290 (K.B., 1697). Although this is probably the earliest pronouncement at common law (Shower refers to another case decided in Exchequer Chamber, but it is not reported; Abbot, op. cit. supra note 63, at 844.), there is little doubt that it was used as a trading device long before 1697. As early as 1538, in the case of "The Thomas," a copy of a bill of lading is to be found preserved on the records of the Court of Admiralty. 1 Select Pleas in the Court of Admiralty 61 (1538) (Selden Society). And in 1554, another Admiralty decision reproduces a bill of lading in which the master of a ship is to deliver 'into a certain merchant, his factor [i.e. agent] or assigns the aforesaid XV ton and ij pouchions of wine, etc." Tbid.

Although in none of these cases are the effects of the assignment of the bill of lading mentioned specifically, there are records of other decisions in the old Admiralty Courts in which the practice among merchants of transferring rights in goods by delivery of the bill of lading is indicated. In Flute's case, for instance, one finds a ship master being sued in Admiralty for delivering a bar of silver to a person who had fraudulently obtained the bill of lading. Ibid. To what extent and with what effect the practice of indorsing the document had also grown up in this early period is not clear, however. But the fact that the eighteenth-century reports speak of indorsement of bills of lading as being a well established custom would seem to indicate that it did have considerable significance even at that time. For an introduction to the early history of bills of lading generally, as well as to their assignability, consult Bennett, The History and Present Position of the Bill of Lading as a Document of Title for Goods (1914).

${ }^{65}$ It was only with the passing of the Bill of Lading Act in 1855 (18 \& 19 Vict., c. 111) that the bill of lading became fully negotiable. Prior to that time the holder of such a document, even though he had acquired the full legal and equitable property in the goods, could not bring an action on the contract in his own name unless he was an original party to the agreement. See Sewell v. Burdick, 10 App.Cas. 74 (1884).

${ }^{66} 1$ Ld. Raym. 271 (K.B., 1697). The report in Salkild, however, does not contain this dictum. 3 Salk. 290 (K.B., 1697).

${ }^{67} 1$ Atk. 245 (Ch., 1743). 
delivery of the cargo. The plaintiffs claimed that although the bill of lading had been made to the order of $R$, since it had been indorsed by them in blank and sent to $T$ "the instant the goods were loaded on board... [the vessel], the property vested in $\mathrm{T} . "$. 68

Despite finding for the defendant on the grounds that his regaining possession of the goods entitled him to have his lien satisfied out of the proceeds of sale, Lord Chancellor Hardwicke's attitude toward the assignment of the bill of lading is more than a little ambiguous. While explicitly denying that the blank indorsement and delivery of a bill of lading passed any interest in the goods themselves as between consignor and consignee, he still acknowledged the transaction between $T$ and $B$ by providing that any proceeds remaining after $R$ 's advances had been repaid should be used to satisfy B's loan. ${ }^{69}$

Although Snee v. Prescott confronted the courts with the dual mercantile function of the transfer of the bill of lading, it was not until the great case of Lickbarrow v. Mason ${ }^{70}$ that they were called upon to fix the different types of legal interests that could be carved out by the negotiation of the document. Some indication of the difficulties which this task posed for the judiciary can be gathered from the fact that Lickbarrow v. Mason was argued for more than six years, going from the King's Bench to the House of Lords and back again. ${ }^{71}$

68 Ibid., at 246.

${ }^{69}$ The reasons for so doing, however, are not made clear. It is interesting to note that despite Lord Chancellor Hardwicke's statement about the effect of the indorsement and delivery of the bill of lading, from the arguments of plaintiff's counsel in the case it appears the assignees of the bill of lading were in no doubt that they had some interest in the goods as apparently they had insured it. According to counsel, it was "the custom of merchants to borrow money upon bills of lading which had been looked upon as good security." Tbid., at 246 et seq.

${ }^{2} 2$ T.R. 63 (K.B., 1787), rev'd 1 H.Bl. 357 (Ex.Ch., 1790), rev'd and venire de novo ordered, 5 T.R. 367 (H.L., 1793). The various reports of the case, together with Justice Buller's opinion, are all reproduced in 1 Smith's Leading Cases 703 et seq. (13th ed., 1929), to which all future case references will be made.

71 During the course of the protracted litigation of Lickbarrow v. Mason, 1 Smith's Leading Cases 703 (13th ed., 1929), another situation arose in Solomons v. Nissen, 2 T.R. 674 (K.B., 1788), which would have permitted the court to have carved out these interests had it been so inclined. It appeared that $H$ had purchased a quantity of pig lead from the defendant who sent $\mathrm{H}$ the bill of lading indorsed in blank. The plaintiff made advances to $\mathrm{H}$ in the form of acceptances, and in return $\mathrm{F}$ indorsed the bill of lading over to him. Very shortly after this, the plaintiff and H became "partners" in an agreement to sell the cargo on arrival and share the profits together. However, it appears that the partnership existed at the time when the advances were made. $H$ subsequently became bankrupt, and the defendants, as unpaid vendors, stopped the goods in transitz. The plaintiff's action was in trover.

The court's decision in Solomons $v$. Nissen is extremely interesting because of the ambiguity of its approach to the bill of lading as a security and trading device. Apparently it was prepared to recognize the practice of assigning the bill of lading and of accomplishing such an assignment by indorsement and delivery of the document. It was also apparently aware that competing interests in the goods could arise and that it was essential that the assignee dealt with the bill of lading in good faith. Yet, notwithstanding this, and in spite of what appeared to be obvious fraud on the plaintiff's part, the court, in finding quite rightly for the defendant, chose to base its decision upon reasons that made it obvious that its understanding of mercantile matters was far from perfect. By denying the plaintiff's action on the grounds that at the time of indorsement he was aware that the goods were not paid for, the court set a prece- 
The action, one in trover, arose on the following facts: Turing and Sons, merchants in Holland, shipped the goods in question for Liverpool by the order and on the account of Freeman of Rotterdam. The ship's master signed a set of four bills of lading for the goods in the usual form, "unto the order or assigns." Two parts were indorsed in blank by Turing and Sons and sent by them together with the invoice to Freeman on the 22d of July, 1786. The third and fourth parts of the set were retained by Turing and Sons, and the captain, respectively. Three days later Turing and Sons drew a bill upon Freeman for the price of the goods, which he accepted. Subsequently, in order to have the plaintiff, a Liverpool merchant, take possession of the goods and sell them for his account, Freeman sent the 'plaintiff the two bills of lading and the invoice, both documents being in the same state as he had received them originally from Turing and Sons. At the same time, Freeman drew upon the plaintiff, who subsequently accepted the drafts and duly honored them. Freeman became bankrupt before the bills of exchange drawn by Turing and Sons on him became due, and consequently the latter, as drawers, were obliged to take up and pay them. On hearing of Freeman's bankruptcy, however, Turing and Sons indorsed the bill of lading in their possession to the defendants and transmitted it to them together with the invoice, authorizing them to obtain possession of the goods on their behalf. This the defendants did on the arrival of the ship at Liverpool, and they later sold the goods for their principals. The plaintiff, as creditor of Freeman for the amount of the draft, demanded the goods of the defendants and tendered to them the freight and charges; plaintiff did not offer the purchase price, which remained unpaid. ${ }^{72}$

The trial court found in favor of the plaintiff, but was reversed in the Exchequer Chamber. On appeal, the House of Lords reversed the Exchequer Chamber and ordered a new trial. To understand fully the exact nature of the problems confronting the court in this case, it is necessary to follow carefully the particular sales patterns which were involved. Although the pronouncements of Justice Buller were to be regarded as the great authority on this subject for nearly a hundred years, an analysis of the actual transaction reveals clearly that his statements were too broad; and that his attempt to fix the interests passed by assignment of the bill of lading only served to confuse subsequent judges as to the true mercantile significance of such assignments. ${ }^{73}$

In the first place, the evidence seemed to show that the relationship between

dent which, had it been allowed to remain law, would have completely wrecked the flexibility and adaptability of the bill of lading as an integral part of the credit mechanism. As it was, almost twenty years had to pass before Lord Ellenborough distinguished the case out of existence in Cuming v. Brown, 9 East 506 (K.B., 1808).

72 The full trial history of the case is contained in 6 East 20(n) (1805), which includes the very elaborate opinion which Justice Buller delivered before the House of Lords in 1793, and also the statement by the special jury concerning the custom of merchants as regards bills of lading and the passing of property.

${ }^{73}$ See Sewell v. Burdick, 10 App. Cas. 74, 98 (1884). 
Turing and Sons and Freeman was that of seller and buyer. The indorsement in blank and delivery of the bill of lading by the seller, if it passed the whole interest in the goods, passed it as a result of and in keeping with the underlying contract between the parties. Between Freeman and the plaintiff, however, the relationship was not that of seller and buyer, but that of consignor and consignee. The transaction was patently not one which involved trading to order. Freeman's instructions to the Liverpool merchant were to sell the goods on his account; that is, to act as a factor for him. Justice Buller in his opinion before the House of Lords, however, stated that as these words were not to be found in the bill of lading itself they could not alter the nature and construction of the document, and even if the plaintiff was considered a factor it would not make any difference. His words on this subject are revealing:

Supposing that the plaintiffs are to be considered as factors, yet if a bill of lading, as I shall contend presently passes the legal property in the goods, the circumstance of the plaintiffs being liable to render an account to Freeman for these goods afterwards will not put Turing in a better condition in this case; for a factor has not only a right to keep goods till he is paid all that he has advanced or expended on account of the particular goods but also till he is paid the balance of his general account. ${ }^{\text {t4 }}$

The import of these words was apparently that the bill of lading possessed an inherent power to pass the entire legal interest in the goods, and that the underlying contract from which it stemmed was ineffective to prevent this complete transfer, even as between the contracting parties themselves, unless a limitation appeared on the face of the bill itself.

By adopting such a position, Justice Buller prevented himself from achieving the delicate balance required by the demands of trade and finance. Although he saw quite correctly that financing by a factor made the latter's interest in the goods different from that of an ordinary agent, he did not see that it also made it different from that of an ordinary purchaser. The difference, as has been seen, was that the goods were regarded by the factor primarily as security for money advanced; that the factor normally derived his profit from interest and commission and not from re-sale; and that his interest in the goods was not that of a manufacturing-purchaser or a wholesaling-purchaser which could only be satisfied by full owmership, but essentially that of a creditor. ${ }^{75}$ To satisfy this security interest did not require that the factor should become owner of the goods (and thereby become no different from an ordinary purchaser), ${ }^{76}$ but only that, in the event of bankruptcy, his interest should have priority over all others to the extent of his advances.

711 Smith's Leading Cases 703, 733 (13th ed., 1929).

75 This applied equally, of course, to third party financing of the factor himself. Again, all that these third parties required was a secured interest in the goods and not the full ownership itself.

${ }^{76}$ It was, of course, to avoid the risks of this position that the merchant undertook his factorage operations in the speculative periods of the nineteenth century. Consult discussion at 258 supra. 
In reviewing the authorities, Justice Buller missed his own vital distinction from the earlier decision of Bibbert v. Carter, ${ }^{77}$ in which he had concluded, quite correctly, that it was the intent of the parties which determined the disposition of the "property" in the goods. The fallacy in choosing in all cases to divorce the effect of the indorsement of the bill of lading from the underlying contract can be seen by the internal inconsistencies in Buller's opinion in the Lickbarrow case. ${ }^{78}$ The difficulties created by the adoption of this position, however, only became apparent as the bill of lading began to be used with increasing frequency as an instrument of credit. ${ }^{79}$

771 T.R. 745 (K.B., 1787). This was an action brought upon a policy of insurance, on goods which were lost on a voyage. The plaintiffs, merchants in London, procured the insurance for a cargo consigned to them from Jamaica. Prior to the date when the insurance was effected, the bill of lading was assigned to a third party as security for advances made to the consignors. In defending the action the underwriters contended that at the time the plaintiffs had effected the insurance the bill of lading had already been assigned, and that as this served to pass the entire property the plaintiffs had no interest left to insure. The plaintiffs argued that since the transfer of the bill of lading was merely for collateral security, the indorsement did not transfer the entire property in the goods. Finding for the plaintiffs, Justice Buller expressed the opinion that although an indorsement of a bill of lading purported upon its face to transfer the entire property in the goods, this was a presumption subject to the evident intention of the parties and there was nothing to prevent them from coming to a different arrangement. This of course recognized clearly that the assignment of a bill of lading could be the result of either a trading (i.e., sales) transaction or a financing arrangement.

${ }^{78}$ In Godfrey v. Furzo, 3 P. Wms. 185, 186 (Ch., 1733), Lord Chancellor King had stated: "When a merchant beyond sea consigns goods to a merchant in London, on account of the latter, and draws bills on him for such goods; though the money is not paid, yet the property of the goods vests in the merchant in London, who is credited for them, and consequently they are liable to his debts. But where a merchant beyond sea consigns goods to a factor in London, who receives them, the factor in this case being only a servant or agent for the merchant beyond sea can have no property in such goods . . . ; neither will they be affected by his bankruptcy." Justice Buller, when adverting to this dictum in his opinion, said: "The next point there stated (i.e., in Godfrey v. Furzo) is, what is the law of a pure factor without any demand of his own? Lord King says he would have no property. This expression is used as between consignor and consignee, and obviously means no more than that, in the case put, the consignor may reclaim the property from the consignee. The reason given by Lord King is, because in this case the factor is only a servant or agent for the merchant beyond sea. I agree, if he be merely a servant or an agent, that part of the case is also good law, and the principal may retain the property. But then it remains to be proved that a man who is in advance, or under acceptances on account of the goods, is simply and merely a servant or agent; for which no authority has been, or as $\mathrm{I}$ believe can be produced." Lickbarrow v. Mason, 1 Smith's Leading Cases 703, 736 (13th ed., 1929).

For Justice Buller to maintain this position, however, obviously necessitated going behind the actual transfer of the bill of lading and examining the relationship between the shipper and the receiver of the goods; an action which was clearly inconsistent with his view that an assignment of a bill of lading $i p s o$ facto passed the entire property in the goods.

79 One of the indications of the unsatisfactory nature of the decision of Lickbarrow v. Mason, 1 Smith's Leading Cases 703 (13th ed., 1929), was the frequency with which litigation concerning the bill of lading occurred during the nineteenth century. Apparently only the judges could acclaim the propriety and authority of Justice Buller's opinion with any degree of en thusiasm. Notwithstanding its obvious dissatisfaction, however, the mercantile community was destined to live with the ruling for almost a hundred years until in Sewell v. Burdick, 10 App. Cas. 74 (1884), the House of Lords finally gave expression to the necessary refinements of Justice Buller's judgment. 
Haille ข. Smith, ${ }^{80}$ which occurred nine years later, showed clearly that such a position could produce obviously incongruous results. ${ }^{81}$ In that case the plaintiffs, a firm of merchant-bankers, brought an action in trover against the captain of a ship to recover the value of a cargo of hemp and iron. V, a firm of merchants in Liverpool, wishing to draw upon the plaintiffs' banking house in London had agreed, inter alia, to consign goods as security to the merchant house of $S$ and $A$ which was made up of the same partners as the banking establishment. $V$ accordingly remitted an invoice of a cargo, together with the bill of lading indorsed in blank to $\mathrm{S}$ and $\mathrm{A}$, but the cargo, although loaded on board the ship, was prevented from leaving Liverpool because of an embargo. V, now heavily indebted to the plaintiff, became bankrupt and the cargo was delivered to the assignee in bankruptcy by the ship's captain against whom the action was brought.

The plaintiffs argued that the indorsement and delivery of the bill of lading transferred the entire property to them, and, therefore, that the goods were rightfully theirs. For the defense, it was pointed out that the goods were only consigned as collateral security, and the risk and charges attendant on them were still with the consignor. It was argued that this, plus possession, gave the consignor the right to retain the goods, so that the defendant was justified in making delivery to the assignee in bankruptcy.

The arguments of the litigants clearly revealed one of the dilemmas created by Justice Buller's earlier opinion. The transaction specifically stated that the shipment of the cargo was for collateral only. To hold, therefore, that there had been a transfer of full ownership meant interpreting the transaction as something which was completely different from that which it was intended to be. Furthermore, such a holding would involve refuting the defendant's contention that the risk and charges attendant on the goods were still with the consignor, a proposition which of itself appeared to be irrefutable. On the other hand, the bill of lading had been indorsed in blank and delivered, and that, according to Lickbarrow v. Mason, was sufficient to pass the entire property. Chief Justice Eyre's resolution of this difficulty was unsatisfactory, but understandably so. In upholding the plaintiffs' action, he chose to follow Justice Buller's statement of the law, but circumvented its most obvious objection by introducing a trust concept as a smoke screen:82

801 Bos. and P. 563 (Ex. Ch., 1796).

${ }^{81}$ Hibbert v. Carter, 1 T.R. 745 (K.B., 1787) (discussed at note 77 supra), had already indicated some of the incongruities that could follow if everyone dealing with the bill of lading were regarded as a purchaser.

82 The question of who would have been liable to the beneficiary bank for its advances had the goods been destroyed in transit after the merchant house of $S$ and $A$ had received the bill of lading would have been an interesting one. Presumably, from the Chief Justice's statement, it would have been $S$ and $A$, as trustees. It is diffcult, although not entirely impossible, to imagine a court arriving at this decision. If the courts were not ready to adapt their concept of "property" to satisfy and give effect to the varying financial interests which the mercantile community was carving out of one chattel and one cargo, interests which to the legal mind 
The case is now brought to point in this one short proposition, viz. That the property was transferred to Smiths and Atkinson [the merchant house] upon a trust in which those who transferred the property, and the banking-house were concerned. If this can be maintained, all the objections which occur so forcibly upon the notion of a bargain and sale, will be removed..$^{83}$

The Haille case indicated the difficulties inherent in the Lickbarrow decision. Did the financier who was interested in the goods merely as security want the entire risk of loss that passed with the property? Was the original vendor, if unpaid in full, left with nothing but a claim for money against the factor, if the latter had used the bill of lading to raise capital? Was the factor required every time he wished to obtain funds to sell his inventory regardless of market prices? And, if freight charges were outstanding, who was to pay-the owner, the financier?

A makeshift device such as that employed by Chief Justice Eyre could not continuously be applied to all the problems arising out of bill of lading transactions. Justice Buller had given great impetus to the use of the bill of lading as a trading device, but he had accomplished this at the expense of the other function of the document. A counterbalance was needed, and, in 1833, equity indicated a method whereby this could be achieved. In In the Matter of Westzinthus ${ }^{84}$ the vendor of goods was claiming the proceeds of the sale of a cargo of oil. The facts of the case were before the Court upon the award of an arbitrator. It appeared that Westzinthus shipped to order a cargo of oil to Lapage and Company, a firm of merchants in Liverpool. The bill of lading, together with a bill of exchange, was transmitted to Westzinthus's agent in England with instructions to deliver the bill of lading to Lapage and Company if, and when, they accepted the bill of exchange. This was done. Hardman and Company, who were in the habit of making advances (by cash and acceptances) on goods placed in their hands by Lapage and Company, in consideration for the assignment of Westzinthus's bill of lading and as a further advance for goods already in their possession, accepted a number of drafts drawn by Lapage and Company. Some time after

must have appeared to be only tenuously connected to its monolithic category of "property," and, therefore, very easily separated from it; it was hardly likely that they would divorce the idea of risk of loss of the goods from the "property" in them. After all, if no goods were in existence how could one have "property" in them? Yet there were other decisions in the field of marine insurance which revealed quite clearly that merchants all thought in terms of risk and of insuring those risks.

The introduction of the trust idea should, of course, have been unnecessary, but Lickbarrow v. Mason, 1 Smith's Leading Cases 703 (13th ed., 1929), was far too imposing an authority to ignore. In faimess to Chief Justice Eyre, however, it should be noted that he recognized the limited value of his methods and took pains to limit the decision to the facts of the particular case.

${ }^{83}$ Haille v. Smith, 1 Bos. and P. 563, 569 (Ex. Ch., 1796). It is obvious, however, that this was no answer to the defendant's contention. For further examples of this same type of diffculty resulting from the initial failure to distinguish the dual purpose of the bill of lading, examine Meyer v. Sharpe, 5 Taunt. 74 (C.P., 1813); Lucas v. Dorrian, 7 Taunt. 278 (C.P.: 1817).

815 B. \& A. 817 (K.B., 1833). 
these transactions had occurred, Lapage and Company became bankrupt and the acceptance held by Westzinthus was dishonored. The latter then served notice on the master of the ship that he claimed the right to stop in transit. Hardman and Company, however, managed to obtain possession of the goods. At the time of the bankruptcy, Lapage and Company owed Hardman and Company $£ 9,271$ on account of advances, as security for which the latter held, besides the bill of lading, Lapage's goods to the value of $£ 9,961$.

The court held that Westzinthus had a right to insist upon the proceeds of Lapage's other goods being first appropriated to the discharge of Hardman's lien and, as they proved sufficient to satisfy it, he had a right to receive the entire proceeds that the sale of the oil would realize. Lord Denman's reasoning in reaching this conclusion merits very close examination as it marks the first. inroad on the Lickbarrow doctrine. In the course of his opinion, Lord Denman pointed out:

As Westzinthus would have had a clear right at law to resume the possession of the goods on the insolvency of the vendee, ${ }^{85}$ had it not been for the transfer of the property and right of possession by the indorsement of the bill of lading for a valuable consideration, to Hardman, it appeared to us in a court of equity, such transfer would be treated as a pledge or mortgage only, in analogy to the common case of a mortgage of a real estate, which is considered as a mere security, and the mortgagor as the owner of the land. We therefore think that Westzinthus, by his attempted stoppage in transitu, acquired a right to the goods in equity (subject to Hardman's lien thereon) as against Lapage and his assignees, who are bound by the same equities that Lapage himself was. And this view ... agrees with the opinion of Mr. Justice Buller, in his comment on the case of Snee v. Prescott and Lickbarrow v. Mason. ${ }^{86}$ If, then, Westzinthus had an equitable right to the oil, subject to Hardman's lien thereon for his debt, he would, by means of his goods, have become a surety to Hardman for Lapage's debt, and would then have a clear equity to oblige Hardman to have recourse against Lapage's own goods, deposited with him, to pay his debt in ease of the surety; and all the goods, both of Lapage and Westzinthus, having been sold, he would have a right to insist upon the proceeds of Lapage's goods being appropriated, in the first instance, for the payment of the debt. ${ }^{87}$

${ }^{85}$ Presumably on the basis of a right of stoppage in transitu. See the judgment of Lord Abinger in Gibson v. Carruthers, 8 M. \& W. 321, 336 (Ex., 1841), for the history and nature of this right.

${ }^{86}$ It is difficult to see how Lord Denman arrived at this conclusion. In the first place the consignor, in Snee v. Prescott, 1 Atk. 245 (Ch., 1743), regained and was in possession of the goods at the time of the action. In the second place the action was between the assignees in bankruptcy of the consignee and the agent of the consignor; and in the third place, although the "pawnee" (who was in Hardman's position) was given preference, the reasons for this were never discussed. Justice Buller's comments on this were "that whatever might be the law, the mere fact of a consignor being in possession was a suficient reason for a court of equity to say "We will not take possession from you till you have been paid what is due to you for the goods'." He then goes on to say, "It is apparent that whatever might be the law of the case, in a most elaborate opinion, Lord Hardwicke decided on the equity alone, arising out of the particular circumstances of it, without meaning to set the principles of law on which the present case depends." 1 Smith's Leading Cases 740-41 (13th ed., 1929).

${ }^{87}$ In the Matter of Westzinthus, 5 B. \& A. 817, 834 (K.B., 1833). 
Thus, Lord Denman, having first accorded due recognition to the legal effect of the transfer of the bill of lading, proceeded to introduce the idea of an equitable mortgage where such a transfer was made to raise credit only. By so doing, he not only recognized that the transfer of the document was something entirely different from a purchase or sale, but, by analogizing it to a mortgage of real estate, he managed to give it an effect more in keeping with the intention of the parties. Admittedly, it was a cumbersome analogy and the confusion of the concepts of "property" and the "right of possession" was still somewhat bewildering. ${ }^{88}$ Yet, as a gloss on Lickbarrow v. Mason, it was undoubtedly of major importance in enabling the courts, especially of equity, to approach future problems of this type in a realistic manner. A court of equity could at once recognize the Lickbarrow doctrine and at the same time ignore its deleterious effects. Thus it could focus attention upon the real nature of the transaction and, in so doing, work out the rights and obligations of the various types of holders more accurately and more fairly.

The mercantile community did not overlook the significance of this gloss. In Spalding . Ruding, ${ }^{89}$ the question of priorities between the plaintiff-vendors and the third-party creditor-indorsees of the bill of lading was again argued before a court of equity. S, acting as the plaintiffs' agent, had sold the cargo to $\mathrm{W}$, who at the time of receiving the bill of lading accepted certain bills of exchange drawn on him by the plaintiffs. W later pledged the bill of lading to the defendants as security for an advance. Subsequently $W$ became bankrupt and the acceptances held by $S$ for the plaintiffs were dishonored. $S$ refused to allow the master of the ship to part with the cargo, but on being informed that the defendants possessed an indorsed bill of lading, they allowed them to obtain it without prejudice to his claim for the proceeds.

The defendants maintained that they were entitled to the entire proceeds of the sale in satisfaction of the general account existing between themselves and the bankrupt. The court, however, refused to recognize this contention. It held that, notwithstanding the fact that the defendants had good title in law, the transfer of the goods was for a limited purpose and did not completely destroy the right of stoppage in transitu. ${ }^{90}$ By again recognizing that such a transfer of the bill of lading could be for a limited purpose and in furtherance of something other than a contract of sale, equity clearly marked the way by which the diffculties of the Lickbarrow doctrine could be overcome. ${ }^{91}$

${ }^{88}$ Lord Denman's recognition of the transfer of the bill of lading as a security was very helpful; his analogy of the mortgage involving the additional concept of "right of possession" was less fortunate. Luckily the court did not at that time trouble themselves with the unnecessary problem of deciding whether such transaction was in fact a mortgage or a pledge. See Sewell v. Burdick, 10 App.Cas. 74 (1884) (discussed at 278-81 infra).

896 Beav. 376 (Ch., 1843).

${ }^{90}$ The court relied on In the Matter of Westzinthus, 5 B. \& A. 817 (K.B., 1833), even though in this case a marshalling of assets was not possible.

91 It should be remembered that the notion of a limited transfer was not new to the law. Hibbert v. Carter, 1 T.R. 745 (K.B., 1787). In this particular case, equity's achievement lay 
The willingness of the common law to adopt this counterbalance was made apparent six years later in Jenkyns v. Brown. ${ }^{22}$ Using his own money, the plaintiff's agent, $K$, had purchased a quantity of corn for his principal. He then drew upon the plaintiff for the purchase price, using a bill of exchange which expressly recited that it was drawn on account of the corn. $\mathrm{K}$ sold the bill to the defendant, giving him at the same time the indorsed bill of lading to K's order with instructions that if the bill of exchange was not honored by the plaintiff the defendant was at liberty to sell the goods. The plaintiff accepted the bill of exchange, but failed to honor it and the defendant thereupon sold the corn. In an action in trover, the Queen's Bench refused to disturb the verdict given in favor of the defendant, pointing out:

By delivering this bill of lading, indorsed to the defendant, as a security for the payment of the bills of exchange drawn on the plaintiff for the value of the cargo, and giving power to sell in case of failure of payment (the bills of exchange having been purchased by the defendant), they passed to the defendant for value a special property in the cargo; and by afterwards sending the invoice with the bills of exchange and letters of advice to the plaintiff they passed to him the general property in the cargo subject to the special property..$^{93}$

The merchant financier's possession of the bill of lading, correctly regarded by equity as being for a "limited purpose," 94 was thus recognized by the common law as giving the possessor a "special property"95 in the goods represented by the document. Although the Queen's Bench could not escape completely the entanglements of the "property" concept, it was becoming aware of the necessity for refining it in order to achieve maximum flexibility in furthering the aims of commerce. As was to be expected, this awakening consciousness was a slow and painful process. Not all judges, even at this stage, realized the need for these changes; not all of them understood the requirements and mechanisms of trade and finance. Some members of the bench, with the best of intentions, still obfuscated the issues by over-generalization and woolly conceptualization. ${ }^{96}$ Others, however, more cognizant and more familiar with commercial needs were quicker to perceive the necessity of abandoning this rigid thinking if the law was to accomplish anything. Thus one finds Justice Blackburn, in the case of Calcutta and Burmah Steam Navigation Company v. DeMattos, ${ }^{97}$ scrupulously avoiding any mention of the word "property" when discussing the security function of the bill of lading:

not so much in fulfilling, as in reminding the common law that there had been decisions regarding bills of lading before Lickbarrow v. Mason, 1 Smith's Leading Cases 703 (13th ed., 1929).

9214 A. \& E. 496 (Q.B., 1849).

${ }^{93}$ Ibid., at 502-3, per Justice Coleridge.

${ }^{94}$ Spalding v. Ruding, 6 Beav. 376 (Ch., 1843).

${ }^{95}$ See also Turner v. Trustees of the Liverpool Dock, 6 Ex. 543 (Ex. Ch., 1851).

* E.g., Short v. Simpson, I.R. 1 C.P. 248, 250 (1866); Chartered Bank of India, Australia, and China v. Henderson, L.R. 5 P.C. 501-2 (1874); The Emilien Marie, 44 L.J. Adm. 9 (1875).

${ }^{97} 32$ L.J.Q.B. 322 (1863). 
The bill of lading is handed to them so as to give them the actual, de facto, dominion over the goods, and to confer upon them the power of giving to a third party, by a sale or pledge of that bill, what that third person would believe to be a rightful dominion over the goods. This, too, is consistent with the bill of lading being delivered to the company merely with a view to give them an effectual security for an advance. ${ }^{98}$

Notwithstanding this progress, the question of what interest actually passed by delivery of an indorsed bill of lading still troubled many judges. To most of the judiciary Lickbarrow v. Mason was still the cornerstone of their thinking as regards the bill of lading, and while they recognized the necessity of refining its overstatement when the transfer of the document was not made in pursuance of a sale, they still believed this could be accomplished without weakening the basic common law proposition as put forth by Justice Buller. By adopting equity's position that such a transfer amounted to a mortgage ${ }^{99}$ of the goods, many courts were able to maintain the accepted conceptual status quo in law and allow the "property" to pass by indorsement and delivery, but protect the indorser-debtor (and those claiming under him) by permitting him to retain an equity of redemption. ${ }^{100}$

Other members of the bench thought it wiser wherever possible to give effect to the transaction without categorizing the transfer as either a mortgage or a pledge. In Kempt v. Falk, ${ }^{101}$ for example, Lord Blackburn, while stressing the underlying transaction, took great pains to avoid placing it in either category. The deliberate ambiguity of this approach, reflecting an obvious dissatisfaction with Lickbarrow v. Mason, could not be maintained indefinitely. And, in Sewell v. Bur$d i c k,{ }^{102}$ it had to be abandoned at least partially. In that case the courts were confronted with a choice of either accepting the pronouncement of Justice Buller as regards the passing of the "property" or else drastically limiting it. The issue presented was whether the indorsee of a bill of lading taken as

${ }^{98}$ Ibid., at 329. Compare the remarks of Lord Selbourne in City Bank v. Barrow, 5 App. Cas. 664,670 (1880).

${ }^{9}$ First suggested, however, only as an analogy: In Re Westzinthus, 5 B. \& A. 817 (K.B., 1833).

${ }^{100}$ This view was adopted in some instances both by law and equity as being the actual effect of such a transfer. E.g., McNee v. Gorst, L.R. 4 Eq. 315 (Ch., 1867); Pigott v. Pigott, L.R. 4 Eq. 549 (Ch., 1867); Rodger v. Comptoir D'Escompte de Paris, 38 L.J.P.C. 30 (1869). See particularly the opinion of Lord Justice Brett in Glyn v. East and West India Dock Co., 6 Q.B. 475 (C.A., 1880). But see Meyerstein v, Barber, L.R. 2 C.P. 38 (1866), where Justice Willes classifies such a transfer as a pledge. Conceptually, however, this last case is riddled with confused dicta. For example, Justice Willes's statements as to the holding of In Re Westzinthus, 5 B. \& A. 817 (K.B., 1833), conflicts with his view that the transfer of the bill of lading is a pledge. Lords Hatherly and Westbury in the same case before the House of Lords regarded it as a mortgage, L.R. 4 H.L. 317, 324, 335, 336 (1870), although the latter continually refers to the mortgagee as pledgee. Ibid., at 335-36.

1017 App. Cas. 573 (1882). See also the same judge in Glyn v. East and West India Dock Co., 7 App. Cas. 591, 604 (1882), and the extremely lucid opinion of Lord Justice Bowen in Sanders v. Maclean, 11 Q.B.D. 327, 341 (1883).

10210 App. Cas. 74 (1884). 
security of advances was liable to the shipowners for freight and other outstanding charges. The Bills of Lading Act ${ }^{103}$ provided:

Every Consignee of Goods named in a Bill of Lading ... to whom the Property in the Goods therein mentioned shall pass, upon or by reason of such Consignment or Indorsement, shall . . . be subject to the same Liabilities in respect of such Goods as if the Contract contained in a Bill of Lading had been made with himself. ${ }^{104}$

Brett, M.R., in his judgment in the Court of Appeals ${ }^{105}$ stated the issue before the court with extreme precision:

Does the indorsement of a bill of lading as a security for an advance, by a necessary implication, which cannot be disproved, pass the legal property in the goods named in the bill of lading to the indorsee, with an equity in the indorser, the borrower, to redeem the bill of lading by payment, or to receive the balance, if any, on a sale? ${ }^{106}$

If it did, then, of course, the indorsee-defendant was liable under the Act. In an elaborate opinion, the Master of the Rolls reiterated his position in Glyn v. East and West India Dock Co. ${ }^{107}$ and vigorously affirmed the position taken by Buller, $\mathrm{J}$., in Lickbarrow v. Mason. His conception of mercantile practice, like Justice Buller's, seemed curiously shortsighted and somewhat confused.

Lord Justice Bowen, in a dissenting opinion which was later adopted by the House of Lords, approached the subject far more pragmatically:

What property, if any, in a cargo afloat passes upon delivery of an indorsed bill of lading, appears to me to be a question of fact in each case that depends, so far as the rights between themselves of the immediate parties are concerned, on the express or implied agreement between them.... The freedom of disposition, which owners of property possess when their property is on shore, belongs to them equally when it is afloat. They can if they please sell the bill of lading, or transfer it upon terms which amount either to a mortgage or to a pledge. For a bill of lading is a symbol of the goods themselves. The cargo being at sea, no actual delivery of it is possible before the ship arrives. During this period of flotation and transit the bill of lading becomes and remains a token or symbol of the goods, and the delivery and indorsement of the bill of lading is equivalent, so far as the passing of property is concerned, to a symbolical delivery of the goods. Upon principle and reason, therefore, apart from authority, one would suppose that it is to the agreement between ... them that we should look to determine the legal consequences that follow on the corporate delivery of the goods. ${ }^{108}$

Lord Justice Bowen saw what neither Justice Buller nor Master of the Rolls Brett could see, that when the document was transferred as security, the parties obviously intended a different consequence than if the transfer were made in

${ }^{103} 18$ \& 19 Vict. c. 111 (1885).

$104 \mathrm{Mbid}$., at $\S 1$.

${ }^{105}$ Burdick v. Sewell, 13 Q.B.D. 159, 160 (C.A., 1884).

${ }^{106}$ Ibid., at 161.

1076 Q.B.D. 475, 480 (C.A., 1880). Compare Sanders v. Maclean, 11 Q.B.D. 327, 334 (1883), in which the same judge departed from Justice Buller's pronouncement and made intent the decisive factor.

${ }^{108} 13$ Q.B.D. $159,170-71$ (C.A., 1884). 
pursuance of a bargain and sale. To give legal effect to such an intention as between the same two parties it was unnecessary to go as far as Justice Buller. The consequences of so doing would completely obscure the distinction between the financing of trade and trading itself, two activities which long before 1884 had separated into their own highly specialized sphere of operation. ${ }^{109}$

Notwithstanding Lord Justice Bowen's strong criticism of Lickbarrow v. Mason, the decision still had nearly a hundred years of authority behind it, plus all the apparent weight of the House of Lords. It remained, therefore, for Lord Blackburn in the same House to completely and explicitly nullify its derogatory effects, and, after ninety-one years, authoritatively to put the curb on the wellmeant but overstated intentions of Justice Buller. On the final appeal of Sewell v. Burdick, the learned justice emphasized that:

No one, in ordinary language would say that when goods are pawned or money is raised by mortgage on an estate the property either in the goods or land passed to the pledgee or mortgagee and I cannot think that the object of the enactment [the Bills of Lading Act] was to enact that no security for a loan should be taken on the transfer of bills of lading unless the lender incurred all the liabilities of his borrower on the contract. That would greatly and I think unnecessarily hamper the business of advancing money on such securities which the legislature has by the Factors Act shown it thinks ought to be encouraged....

[N]either the statement of the custom of merchants in the special verdict in Lickbarrow v. Mason, nor the opinion of Buller J., justifies the inference that the indorsement of the bill of lading for a valuable consideration must pass the entire legal property, whatever was the intention of the parties. ${ }^{110}$

Although, in reversing the Court of Appeals, the House of Lords specifically chose to regard the nature of this particular transfer as a pledge, it is clear that this was only done to avoid even the remotest possibility of bringing the trade financier within the operation of the Bills of Lading Act with respect to the shipping contract contained in the bill of lading itself. To have adopted the view that the transaction was a mortgage would have been too dangerous in this particular instance, since it would have been far too easy to have construed the mortgagee's interest as being the same as the "property" referred to in the Act. ${ }^{111}$ It was this, more than anything else, that was responsible for the court's

${ }^{109}$ Consult discussion at 265 supra.

${ }^{110}$ Sewell v. Burdick, 10 App.Cas. 74, 95, 100 (1884).

111 As indeed Master of the Rolls Brett, Lord Baggallay and Justice Field had done in the lower courts. Burdick v. Sewell, 10 Q.B.D. 363 (1883), 13 Q.B.D. 159 (C.A., 1884). In Glyn v. East and West India Dock Co., 6 Q.B.D. 475, 480 (C.A., 1880), Lord Justice Brett had expressed an opinion that to regard the indorsement and delivery of the bill of lading for an advance as a pledge was inconsistent with Lickbarrow v. Mason, 1 Smith's Leading Cases 703 (13th ed., 1929).

As regards the indorsee's right of suit under the bill of lading, this was rightly only accorded to him when he did some further act to take possession of the goods themselves. See Lord Selbourne's opinion in Sewell v. Burdick, 10 App.Cas. 74, 88-89 (1884). 
conceptualizing the security interest and regarding it as a pledge rather than a mortgage. ${ }^{112}$

\section{Legal RECOGNITION OF THE FACTOR AS A Financier of Overseas Trade}

Although the rise of the factor as a purveyor of credit in the nineteenth century also created problems for the courts, their solution acquired a much greater sense of urgency than those connected with the instrument of credit itself. This was not only on account of the importance of the commission merchant in international trade, but also because the attitude of the law was so out of step with the changing patterns of dealing in this area as seriously to jeopardize the entire credit structure of the system.

Much of the trouble stemmed from the old case of Paterson $v$. Tash ${ }^{113}$ in which Chief Justice Lee, in examining the activities of the factor, had stated that although he had power to sell, and thereby bind his principal, he could not bind or affect the property of the goods by pledging them for his own debt. ${ }^{114}$ Such a narrow interpretation of the function of the commission merchant, as being no more than a buying or selling agent, although to some extent understandable as a mid-eighteenth century view, was hopelessly outdated by the nineteenth century.

The fact that the full import of this decision was not to become apparent for more than fifty years resulted in its extension by subsequent decisions to include transactions involving bills of lading and other indicia of title, in addition to the goods themselves. ${ }^{115}$ It was only when the importance of the factor began to increase, and his financial operations to ramify, that the seriousness of the problem created by this rule became apparent. Refusal to allow the commission merchant the use of his inventory as a means of financing both himself and his consignor $^{116}$ threatened to disrupt the entire credit mechanism of overseas trade. ${ }^{117}$

112 Lord Blackburn pointed out that in his opinion the rights were in substance the same whether the transfer was regarded as a pledge or a mortgage. He refused to say, however, whether a mortgagee's interest would, in these circumstances, bring the indorsee within the provisions of the Bills of Lading Act. Ibid., at 103.

${ }^{113} 2$ Str. 1178 (K.B., 1743).

${ }^{114}$ There are a number of grounds for maintaining that Paterson v. Tash, 2 Str. 1178 (K.B., 1743), was really no authority for this rule. Chief Justice Gibb stated that it had been misreported. Parl. Papers, Report on Merchants, 1823, 75, 769. And it has been suggested that there was some form of collusion between the factor and the pledgee. Pearson-Gee, The New Factors Acts 3 n. (c) (1889).

116 For cases in which the rule was applied to documents representing goods, see Newsom v. Thornton, 6 East 17 (K.B., 1805); Shipley v. Kymer, 1 M. \& S. 484 (K.B., 1813); Graham v. Dyster, 6 M. \& S. 1 (K.B., 1817); Barton v. Williams, 5 B. \& A. 395 (K.B., 1822). In Pultney v. Keymer, 3 Esp. 182 (N.P., 1800), however, Lord Eldon ignored it entirely.

${ }^{116}$ Except, of course, where there was actual authority from the consigning owner.

${ }^{117}$ Consult discussion at 258-63 supra. 
As a result of this situation, Parliament set up a select committee in 1823 to examine the law relating to merchants, agents and factors, the outcome of which was the adoption in the same year of what was destined to be but the first of a series of Factors Acts ${ }^{118}$ designed to abrogate the rule in Paterson v. Tash and to give adequate recognition and protection to the operations of the commission merchant. The enactment of 1823 was concerned solely with the immediate problem of safeguarding the interests of both the financier who advanced against the factor's inventory, and the consignor whose commission agent had become bankrupt while still in possession of the consignor's goods. While the Act appeared to show some appreciation of the inadequacy of the law from a mercantile point of view, in effect, it did very little to offset the rule of Paterson v. Tash $^{119}$ It did, however, permit a factor to transfer his lien upon a consignment against which he had made advances by pledging the goods or bill of lading, ${ }^{120}$ therebyreversing the old commonlaw rule that a pledge by a factor of goods in his possession was so tortious as to prevent the passing of even his own lien.121

The shortcomings of this legislation were so obvious that two years later Parliament amended the Act. ${ }^{22}$ After confirming the provisions of the earlier statute protecting the consignee's lien as against the consignor, the amendmients increased the rights which the pledgee might obtain by providing that his interest in the goods extended to their entire value and not just to the pledgor's interest therein. ${ }^{123}$ Lack of notice by the pledgee of the factor's limited interest in the goods was, as in the previous statute, retained as a condition, ${ }^{124}$ but the amendments further changed the earlier Act by providing that even though the pledgee had notice, his interest was valid to the extent of the factor-pledgor's lien on the goods. ${ }^{125}$ While the amendments represented a step forward from the Act of 1823, to a banker or financièr accustomed to dealing in this sphere with any frequency, the safeguards provided were all but useless. As the Act stood, and as the bench was subsequently to construe it, its real accomplish-

$1184 \mathrm{Geo}$ IV, c. 83 (1823). The various acts following the 1823 statute were as follows: $6 \mathrm{Geo}$. IV, c. 94 (1825); 5 \& 6 Vict., c. 39 (1842); and 40 \& 41 Vict., c. 39 (1877). The last Act, 52 \& 53 Vict., c. 45 (1889), was a codification of the previous statutes.

119 One legal writer, however, regarded the Act as considerably modifying the then existing law. Russell, A Treatise on Mercantile Agency 100 (2d ed., 1873).

${ }^{200}$ Geo. IV, c. 83, §2 (1823).

121 Daubigny v. Duval, 5 T.R. 604 (K.B., 1794). In connection with this lien between consignor and consignee, Lord Blackburn pointed out in 1883: "[I]ts [the Factors Act of 1823] provisions have, in practice, been found to work so harmoniously with the practice of merchants that I am not aware that any case has ever arisen requiring a court of law to construe it." Mildred v Maspons, 8 App.Cas. 874, 884 (1883).

1226 Geo. IV, c. 94 (1825).

123 Ibid., at $\$ 2$.

124 Tbid.

${ }^{125}$ Ibid., at $\$ 5$. This right was also the same where the security was given for a pre-existing debt. Ibid., at $\$ 3$. As to what constituted a pre-existing debt within the Act see Jewan v. Whitworth, L.R. 2 Eq. 692 (Ch., 1866); Macnee v. Gorst, L.R. 4 Eq. 315 (Ch., 1867). 
ment was negligible as regards abrogating the rule of the Paterson case. ${ }^{126}$

The English courts showed no disposition to relax the constricting rules of the common law as regards the pledging of goods or documents by the factor. In fact such a completely literal interpretation of the statute was adopted that they all but reduced the financier to his former insecure position. Their reading of the Act did nothing to avoid the difficulties that bad draftsmanship was capable of creating; and it ultimately resulted in placing several distinct barriers between the would-be trade financier and a safe and satisfactory security.

Under Section 2 of the Act, for the financier to obtain the benefits of his security, it was essential that he should not have notice that the person pledging the documents was not the actual owner of them. In construing this section, the justices followed exactly the same rule as was laid down at common law prior to the Act. "Notice" was construed as including any circumstance which would cause a reasonable man to believe that the goods or documents offered as security were not the property of the person so offering them..$^{127}$

Apart from this provision, which, together with its construction, more or less negated any advantages which the Act may have had, the courts proceeded to attach further excrescences to the statute which limited its effect even further. Section 2, besides containing the notice provision, also provided "that any person intrusted with, and in possession of any bill of lading, India warrant, dock warrant, warehouse keeper's certificate, wharfinger's certificate, warrant or order for the delivery of goods, shall be deemed and taken to be the true owner. thereof," so as, inter alia, to give him the power of pledging the same. The distinction made by the legislature between the words "intrusting" and "possession" indicated that the former implied something more than the latter, but the content of the distinction remained for the courts to decide. The first important decision on this subject was Close v. Holmes. ${ }^{128}$ The plaintiffs had been in the habit of employing one $\mathrm{H}$, a commission agent who resided in Hull, and making consignments of goods to him to sell for their account. Holmes, the defendant, was the registered officer of The Hull Banking Company. In the months of

${ }^{28}$ The Act, however, did show some recognition of the difference in function between financier and trader by allowing the owner of the goods to re-obtain them from the former on satisfying the factor's lien. $6 \mathrm{Geo}$. IV, c. $94, \S 6$. This, of course, was not very satisfactory from the financier's point of view as conceivably the sums advanced by the commission merchant to the owner were far less than those advanced by the financier to the factor on the same security.

${ }_{127}$ Newsom v. Thornton, 6 East 17 (K.B., 1805); Graham v. Dyster, 6 M. \& S. 1 (K.B., 1817); Evans v. Trueman, 1 M. \& Rob. 10 (N.P., 1830); Taylor v. Trueman, M. \& M. 453 (N.P., 1830). It was this, of course, which made the effect of the Act negligible in abrogating the rule in the Paterson case. The growing dominance of the consignment pattern of dealing in overseas trade at this time made it virtually impossible for a reasonable man to be unaware that the goods and documents offered to him as security were more than likely the property of someone other than the party seeking the advance, especially as those commission merchants who could afford to buy or sell on their own account were generally strong enough not tn seek such advances. Consult discussion at 260-62 supra.

1282 M. \& Rob. 22 (N.P., 1837). 
January and February, 1835, two ships arrived at Hull with cargoes consigned by the plaintiffs to $\mathrm{H}$ for sale on their account. The bills of lading were indorsed in blank by the shippers and transferred to $\mathrm{H}$. $\mathrm{H}$ had the goods landed, and warehoused both cargoes in his own name. In June, 1835, $\mathrm{H}$ applied to the banking company for an advance of money. The request was granted and $\mathrm{H}$ obtained from the warehouse company a written acknowledgment that the cargo warehoused on their premises was being held to the order of the banking company. Upon receipt of this acknowledgment, the bank gave $\mathrm{H}$ its acceptance for five hundred pounds. The banking company later made a further advance on the cargo, this time on the security of the delivery order. On neither occasion did $\mathrm{H}$ produce the bills of lading.

In their action for trover, the plaintiffs replied to the defendant's contention that the bank held the goods under the Factors Act, by maintaining that, as the Act only gave protection to pledges by the factor of the specific documents of title with which the principal had entrusted his agent, Section 2 did not apply. Here the defendants had made advances on a delivery order and a warehouse receipt, neither of which documents had actually been "intrusted" to the factor. All the factor had obtained from his principal were bills of lading, and, therefore, the plaintiffs argued that it was upon the latter documents and these alone that a valid pledge could be made. Baron Alderson, who tried the case, upheld this contention, and pointed out that for the defendant to come within the Act he must clearly show that $H$ had actually been entrusted with the property pledged, a fact of which there was obviously no evidence in the case under consideration.

This conservatism was by no means peculiar to Baron Alderson. It reflected generally the opinions of a bench which saw the concept of "ownership" almost solely in terms of land law and to whom the preservation of such a concept was of paramount importance. ${ }^{129}$ When the same point arose again in Phillips $v$. Huth, ${ }^{130}$ where dock warrants had been issued as collateral instead of the original bills of lading, exactly the same result occurred. In this particular case the Court of Exchequer went so far as to overturn the findings of a jury that the documents pledged had been "intrusted" to the factor and to grant a new trial. Baron Parke, in delivering the judgment, elaborated the rationale upon which this construction of the statute rested:

Intrusting with the document is essentially different from enabling a person to become possessed of it-from giving him the means of obtaining it. . . It is not enough, therefore, to shew that the plaintiffs empowered Warwick, or Warwick \& Clagett [the factors], to possess themselves of the warrants whenever they chose; it must be shewn that the plaintiffs really intended that the factors should be possessed of them at the

${ }^{129}$ For examples of this general conservatism and the opposition to the passing of the Factors Acts, consult 9 Parl. Deb. 211, 256 (Ser. 2, 1823). But cf. Williams v. Barton, 3 Bing. 139, 145 (Ex. Ch., 1825).

1306 M. \& W. 572 (Ex., 1840). 
time they pledged them, or it must be shewn that the plaintiffs meant them not merely to have the power which the possession of the bill of lading would give-of getting the warrants when they [the plaintiffs] liked, but to exercise that power by obtaining it, whenever they [the factors] int their discretion might think fit. If either of these intentions were proved, it would be sufficient. ${ }^{131}$

By placing the burden upon the banker of ascertaining the intention of the principal, the court, far from alleviating the deleterious effects of Paterson $v$. $T a s h$, only added to the financier's burden. Under the common law, he had been required to ascertain only if the factor had the authority of his principal to pledge in order to protect himself. With the passing of the Factors Acts, however, he was compelled first to try to define correctly what the word "intrusting" meant, and then, having done this, to attempt to deduce from all the circumstances whether or not the factor's possession of the documents came within this meaning. Furthermore, the courts, by distinguishing at this stage between "goods" and "documents of title"132 as collateral for loans, had increased the financier's original burden by making such tasks cumulative rather than alternative courses of action.

Another obstacle erected by the courts emanated from the very narrow construction placed upon the phrase "security for any money or negotiable instrument or instruments advanced" in Section 2 of the Act. In Taylor v. Trueman, ${ }^{133}$ the defendants, who had financed $M$ and Company, a firm of commission merchants, were sued by the latter's principal for conversion of certain dock warrants. $M$ and Company were instructed to purchase and did actually purchase for the plaintiff certain chests of indigo, lying in the warehouses of the East India Company, for which they subsequently obtained warrants. Prior to this, $\mathbf{M}$ and Company had borrowed a large sum of money from the defendant and had deposited with the latter other East India warrants for other indigo as collateral. Requiring some of the latter indigo, they applied to the defendants for the release of some of the warrants, on a promise to pay their value during the course of the day. MI and Company failed to do this and instead deposited ten of the plaintiff's warrants as security. It was on account of these latter documents that the plaintiff brought this action in trover.

1316 M. \& W. 572, 598 (Ex., 1840). Also examine Hatfield v. Phillips, 9 M. \& W. 647 (Ex. Ch, 1842) (especially the judgment of Lord Denman at 648), aff'd 14 M. \& W. 665 (H.I., 1845).

132 Phillips v. Huth, 6 M. \& W. 572 (Ex., 1840); Hatfield v. Phillips, 9 M. \&W. 647 (Ex. $\mathrm{Ch}, 1842$ ). In these two cases the courts had limited the Act to those instances where the factor had in his hands some document which showed title to the specific goods. Possession of the goods themselves by the factor did not bring the latter within the Act. This meant, of course, that where the factor attempted to pledge goods in his warehouse, the rule of Paterson v. Tash, 2 Str. 1178 (K.B., 1743), still operated. Prior to the passing of the Act no attempt had been made when applying Paterson v. Tash to distinguish goods from documents of title. To some extent such a distinction could have been accepted if it had been used to circumvent rather than enforce the rule.

1331 M. \& M. 453 (N.P., 1830). 
In allowing the plaintiff to recover, Lord Tenterden stated:

Holding the warrants originally deposited with them as securities, the defendants gave them up, and received the warrants in question in exchange. This does not appear to me a transaction within the second section of the statute.... It is no "pledge or deposit of them as a security for money advanced on the face of them," for the money for which they are a security was previously due, namely on the former transactions, when the warrants for which they were exchanged came into the hands of the defendants. ${ }^{134}$

No doubt the courts were correct in refusing to extend the meaning of the phrase "negotiable instrument or instruments advanced" to include documents of title; but it would not have required much imagination and legal flexibility to have brought the exchange of collateral within the operation of the Act. Fifteen minutes walk from the courts of Westminster to the City of London and Lombard Street were all that were needed to have revealed how common a practice was this substitution of security.

It was obvious that with so many legal impediments, the financing of inter-national trade was in danger of being seriously impaired. As a result of this situation, Parliament passed yet a further statute "to alter and amend"135 the previous Act, and "to extend the Provisions thereof, and to put the Law on a clear and certain Basis. ${ }^{\text {136 }}$ The first important step taken by the new Act was specifically to overturn the rule laid down in Paterson v. Tash. The Act provided:

Any agent who shall ... be intrusted with the possession of goods, or of the documents of title to goods, shall be deemed and taken to be owner of such goods and documents, so far as to give validity to any contract or agreement by way of pledge, lien, or security bona fide made by any person with such agent so intrusted ... and such contract or agreement shall be binding upon and good amongst the owner of such goods, and all other persons interested therein, notwithstanding such pledge or lien may have had notice that the person with whom such contract or agreement is made is only an agent. ${ }^{137}$

In addition, the restriction under which the courts had previously prevented the exchange of collateral from coming within the Act was removed, ${ }^{138}$ as was the unreal distinction between those documents of title which were and those which were not derived immediately from the owner..$^{139}$

${ }^{134}$ Ibid., at 455-56. See also Taylor v. Kymer, 3 B. \& A. 320 (K.B., 1832).

${ }^{135}$ Preamble, 5 \& 6 Vict., c. 39, $\$ 1$ (1842).

136 Ibid.

${ }^{137} 5$ \& 6 Vict., c. $39, \$ 1$ (1842).

138 Ibid., at $\S 2$.

${ }^{139}$ Phillips v. Huth, 6 M. \& W. 572 (Ex., 1840). The new Act stated that "any agent intrusted . . . and possessed of any such document of title, whether derived immediately from the owner of such goods, or obtained by reason of such agent's having been intrusted with possession of the goods, or of any document of title thereto, shall be deemed and taken to have been intrusted with the possession of the goods represented by such documents of title as aforesaid." 5 \& 6 Vict., c. $39, \$ 4$ (1842).

The Act also extended its protection to advances made on goods as well as documents of title. Ibid., at $\$ 1$. Section 4 listed the types and essential elements of these "documents of title." 
Although showing a far more realistic approach to aiding the merchant or banking community, Parliament still had not improved upon its drafting technique. The applicability of the Act still depended upon the transactions involving agents "intrusted with the Possession of Goods ... or of Documents of Title thereto."140 The difficulties created by the use of this wording in the prior acts apparently had not deterred Parliament from again adopting it.141

Justice Blackburn, in the case of Cole v. The North Western Bank ${ }^{142}$ gives the most lucid and comprehensive description of these difficulties. The facts of this case afford an excellent illustration of the legal snares and pitfalls which lay in the path of the banker who was embarking upon this type of financial enterprise. ${ }^{143}$ The plaintiffs, merchants in London, were the owners of two parcels of sheep's wool and two parcels of mohair or goats' wool. All four parcels were received for the plaintiffs by one Slee, a warehouseman and sheep's wool broker at Liverpool, and were by him deposited in his own warehouse at liverpool. The wool was taken by the defendants pursuant to an agreement by which Slee pledged or agreed to pledge all four parcels to the defendants for $£ 7,000$ advanced to him. At the time when the contract was made, two parcels of goats' wool and one of the parcels of sheep's wool were in Slee's warehouse. The other parcel of sheep's wool was still on board the vessel by which it had been shipped originally; but Slee held the bill of lading which had been sent to him by the plaintiffs to enable him to land and deposit the wool in his warehouse. Slee absconded with the $£ 7,000$ which he had obtained, and the defendant, having notice that Slee had committed this act of bankruptcy, but not having any notice that he had not been so "intrusted" with possession of the goods so as

140 Mbid., at $\$ 1$.

111 There was, of course, one major drafting change in this particular provision, and that was the substitution of the word "agent" for "person." The same problem still existed, however. Bennett, op. cit. supra note 64 , at 26 , points out that the use of the word "intrusted" in all the acts prior to that of 1889 , was the subject of so much judicial consideration that it was not reproduced in the 1889 draft. In examining the 1889 Act, Bennett, therefore, considered it unnecessary to examine the previous cases on this point.

Section 2 of the 1889 Act, however, reads: "Where a mercantile agent is, with the consent of the owner, in possession of goods or of the documents of title to goods, any sale, pledge or other disposition of the goods, made by him when acting in the ordinary course of business of a mercantile agent, shall, subject to the provisions of this Act, be as valid as if he were expressly authorised by the owmer of the goods to make the same." 52 \& 53 Vict., c. $45, \$ 2$ (1859). The change in language was only formal; the financier was, and still is, in the position of having to insure that the factor is acting qua factor and not in any other capacity, and this, in effect, poses the same problems as the "intrusting" situation. See, for example, Cole v. North Western Bank, L.R. 10 C.P. 354 (Ex. Ch., 1875), discussed above. A comparatively recent case on the point is Staffs Motor Guarantee, Itd. v. British Wagon Co., [1934] 2 K.B. 305.

One of the reasons why this problem has resulted in so few cases in the present century is the great change in the trading patterns which occurred toward the end of the nineteenth century. An examination of the cases occurring after 1900 in which the courts had to construe the Factors Act of 1889 shows that nearly all of them involve domestic sales by such people as automobile dealers. Consult discussion at $265-66$ supra.

142 L.R. 10 C.P. 354 (Ex. Ch., 1875).

${ }^{143}$ The greatest care is, of course, still required from the merchant banker. 
to be able to pledge them, took forcible possession of all the goods against the will of Slee's clerical staff. ${ }^{144}$

In an action to determine the rights of the parties to the goods, Blackburn pointed out:

The great question was whether Slee was, under the circumstances so intrusted with the possession of the goods as to have been able ... (supposing he had then delivered actual possession to the defendants) to make a pledge to the defendants' goods against the plaintiffs. As to this, there is a distinction between the sheep's wool and the goats' wool; for, Slee never sold goats' wool at all, and was clearly intrusted with the goats' wool as warehouseman, and as warehouseman only. But he did sell sheep's wool as a broker. ${ }^{145}$

In an exhaustive review of the history of the Acts, and the decisions upon them, Lord Blackburn found that as Slee had been "intrusted" not as a broker but as a warehouseman, the defendants could not plead protection of the Factors Acts and the plaintiffs were, therefore, entitled to recover.

Replying to the argument put forth by defending counsel that "the object of the legislature was, to afford facilities for safely making advances; and that this object was only imperfectly carried out if an advance made under such circumstances ... was not protected" and "that the defendants had no means of knowing whether Slee was possessed as a warehouseman or as a broker," ${ }^{146}$ Lord Blackburn pointed out that certainly as regards the mohair, the argument was invalid. He stated:

[I]nquiry would have made the defendants aware that Slee was not a broker for mohair at all. As regards the sheep's wool, however, there is force in the arguments that the defendants might, without much negligence, be led by Slee to believe that he was intrusted with the sheep's wool as a broker. But, if the plaintiffs knew that the warehouseman whom they trusted was also a wool-broker, the defendants were aware that the wool-broker whom they trusted was also a warehouseman; and there seems no reason why without inquiry they should think he was intrusted in one capacity rather than the other.

Probably 5 \& 6 Vict. c. $39 \S 4$, requires us to treat him as being so intrusted, unless the contrary is shewn in evidence. But we are all of opinion that in this case the plaintiffs have shewn in evidence ... that Slee was not intrusted as broker, but solely as warehouseman. We do not think that the legislature wished to give to all sales and pledges in the ordinary course of business the effect which the common law gives to sales in market overt.147 If such had been their object, it could easily have been so enacted in terms; which certainly has not been done. ${ }^{148}$

144 These facts are taken from Lord Blackburn's judgment. Ibid., at 357.

${ }^{146}$ Ibid., at 358.

146 Tbid., at 371.

${ }^{147} \mathrm{It}$ is interesting in this connection to reflect how and why the law of market overt developed in the first place. The creation of the law of market overt and the demand for the "Factors Acts" are in part different solutions to the same problem; i.e., deciding which of two innocent parties is to suffer for the fault of a third. In the Middle Ages, the difficulty was resolved solely in favor of the itinerant merchant trading at the great markets and fairs in Eng- 
A careful reading of this judgment shows without a doubt that, apart from the pressure of prior authority, the learned judge was exercising a deliberate policy choice in adopting such an interpretation. The burden of inquiry which was placed upon the banker was one which the judge thought he should rightfully bear and one which it behooved the prudent financier to accept of his own volition..$^{149}$

That such leeway under the phrasing of the 1842 Act was not always possible, however, was shown by the case of Fuentes $v$. Montis ${ }^{150}$ where the wording of an "agent who shall be intrusted with possession, etc." was again considered. The case was an interpleader issue directed to determine the rights of the litigants to a cargo of wine. The plaintiffs who had consigned a quantity of wine to a factor for sale, having become dissatisfied with him as their agent, terminated his authority and instructed him to hand over the wines to another agent. The factor unlawfully refused to comply with these instructions, and while in wrongful possession of the wines, pledged the dock warrants representing them to the defendants for advances. The defendants pleaded their lien under the Factors Acts.

Both Justice Blackburn (in Assizes) and Justice Willes (in the Common Pleas) found in favor of the plaintiffs. That two judges of such obvious commercial acumen should have been instrumental in placing such a burden on the banking community is somewhat hard to understand..$^{151}$ No doubt to construe "intrusted" to include "having been intrusted" was made difficult by the wording of the statute, but it was by no means an impossible construction. ${ }^{152} \mathrm{~A}$ possible explanation for their action lies in the vast amount of speculation in this type of collateral which was and had been occurring during this period, ${ }^{153}$ and a desire on the part of the bench to introduce a measure of prudence in such dealings. Whether or not this was, in fact, the reason, the net effect of this decision

land. Later, with the emergence of big, organized, and highly specialized institutions, and a division of mercantile functions between trader and banker, a compromise solution evolved resulting in division of responsibility among the two major groups involved. For a general description of trading in the Middle Ages, consult 2 Cambridge Economic History of Europe, c. 4 (1952).

${ }^{148}$ Cole v. The North Western Bank, L.R. 10 C.P. 354, 371-72 (Ex. Ch., 1875).

${ }^{199}$ Lord Blackburn was also undoubtedly influenced by the fact that the old consignment method of dealing was still, even at this time, the regular method of trading in wool, and that dealing in this commodity was very highly specialized. Consult Clapham, op. cit. supra note 2 , at 317 .

${ }^{150}$ L.R. 3 C.P. 268 (1868), aff'd L.R. 4 C.P. 93 (Ex. Ch., 1868).

${ }^{151}$ It is even more difficult to comprehend when one recalls that, under the common law, if plaintiffs contracted to sell goods to defendants and actually sold them, plaintiffs would have been bound by the contract. See Trueman v. Loder, 11 Ad. \& E. 589 (Q.B., 1840).

${ }^{162}$ Lord Blackburn's judgment is not available; but Justice Willes's discomfort is obvious. See Fuentes v. Montis, 3 C.P. 268, 283 (1868).

${ }^{153}$ Consult discussion at 262 supra. 
was to place the financier in virtually the same position as he had been when Paterson $v$. Tash was still law. The nature of the inquiry might be different; its extent was still the same.

Despite the obvious difficulties which this case created, the mercantile community appeared to be relatively undisturbed by it. In fact, it was not until almost ten years later that any attempt was made to overturn the decision. The reasons for this lack of concern are, of course, not hard to determine. The decline of the consignment transaction in the 1850's and 1860's marked the end of the factor's pre-eminence in the field of international trade, both as a purveyor of credit and as a buying and selling agent. This, combined with the emergence of trading to order as the general pattern of dealing, meant that questions of the factor's "authority" and his "intrusting" no longer created anxiety in the trade fnancier as regards the safety of his collateral. Thus it was not until the adoption of a new Factors Act in 1877 that the decision was overturned..$^{154}$

Although this delay was indicative of these changing methods of trade and finance, of far greater significance in this respect were the new provisions of the 1877 Act which enlarged the scope of the phrase "person intrusted" to include the buyer or seller of goods who was allowed to remain in control of the documents of title of which he was not owner. ${ }^{155}$ Not only did they more clearly reflect these developments, but they also showed the new and particular type of difficulty which was accompanying them. The 1877 Act itself as a whole, however, still preserved many of the older legal pitfalls for the merchant banker, as, indeed, did the final codifying legislation which superseded it in $1889 . .^{156}$ Fortunately, with the factor's decline as the dominant figure in foreign trade, many of these legislative defects lost much of their importance. By and large they no longer had any reference to the patterns of trade and finance which then existed.

\section{CONCLUSION}

Though the courts eventually managed, with the aid of the legislature, to resolve the problems presented by documentary finance and factorage, it is evident that they were ill-equipped conceptually to meet the demands of the new economic order. The fact that Justice Buller's opinion in Lickbarrow v. Mason was accepted side by side with Paterson $v$. Tash is itself one of the most obvious indications of the confused thinking which prevailed during this period. If, as Justice Buller contended in Lickbarrow v. Mason, the indorsement and delivery of the bill of lading ipso facto passed the entire property in the goods, then clearly the factor's right to use the document as security for his own debts was beyond question. The adoption of such a position, however, would have neces-

$15440 \& 41$ Vict., c. $39, \$ 2$ (1877).

${ }^{165}$ Ibid., at $\$ \$ 3,4$.

${ }^{156}$ For a general discussion of the 1889 Act (52 \& 53 Vict., c. 45), consult Neish and Carter, The Factors Act, 1889 (1890); Bowstead's Digest of the Law of Agency, 188 (11th ed., 1951); Bennett, op. cit. note 64, at 25-34. 
sitated a virtual denial of the existence of the factorage operation. It would have put the consigning owner in the position of having to regard the factor's advances not as a loan but as the purchase price for the goods. Presumably, it was to avoid this absurdity that the courts ignored Justice Buller's opinion when faced with a problem in which the Paterson v. Tash doctrine was controlling.

No doubt the fluidity of the commercial situation encouraged the judiciary to adhere to those concepts with which they were familiar; but so long as they persisted in regarding "property" as indivisible, it was impossible for them to give effective recognition to the requirements of trade finance. This attitude, as a commentary upon the legal approach to mercantile questions, provides one explanation as to why those engaged in international trade have always preferred, wherever possible, to utilize machinery other than the formal legal system to resolve their disputes. 157

${ }^{167}$ Since the latter part of the nineteenth century, this extra-legal machinery has been provided by arbitration. In former times it was provided by the fair courts of Piepowder. Consult Plucknett, op. cit. supra note 61 , at 622 . It is perhaps worth noting that the first inroad into the Lickbarrow doctrine was made in a case arising out of an arbitration proceeding. In $\mathrm{Re}$ Westzinthus, 5 B. \& A. 817 (K.B., 1833) (discussed at 274 supra). 